\title{
Epigenomic Regulation of Schwann Cell Reprogramming in Peripheral Nerve Injury
}

\author{
Ki H. Ma, ${ }^{1,2}$ Holly A. Hung, ${ }^{1,2}$ and $\oplus^{-J o h n ~ S v a r e n ~}{ }^{1,3}$ \\ ${ }^{1}$ Waisman Center, ${ }^{2}$ Cellular and Molecular Pathology Graduate Program, and ${ }^{3}$ Department of Comparative Biosciences, University of Wisconsin, Madison, \\ Wisconsin 53705
}

The rapid and dynamic transcriptional changes of Schwann cells in response to injury are critical to peripheral nerve repair, yet the epigenomic reprograming that leads to the induction of injury-activated genes has not been characterized. Polycomb Repressive Complex 2 (PRC2) catalyzes the trimethylation of lysine 27 of histone H3 (H3K27me3), which produces a transcriptionally repressive chromatin environment. We find that many promoters and/or gene bodies of injury-activated genes of mature rat nerves are occupied with $\mathrm{H} 3 \mathrm{~K} 27 \mathrm{me} 3$. In contrast, the majority of distal enhancers that gain $\mathrm{H} 3 \mathrm{~K} 27$ acetylation after injury are not repressed by $\mathrm{H} 3 \mathrm{~K} 27 \mathrm{methylation}$ before injury, which is normally observed in developmentally poised enhancers. Injury induces demethylation of $\mathrm{H} 3 \mathrm{~K} 27$ in many genes, such as Sonic hedgehog $(S h h)$, which is silenced throughout Schwann cell development before injury. In addition, experiments using a Schwann cell-specific mouse knock-out of the Eed subunit of PRC2 indicate that demethylation is a rate-limiting step in the activation of such genes. We also show that some transcription start sites of H3K27me3-repressed injury genes of uninjured nerves are bound with a mark of active promoters H3K4me3, for example, Shh and Gdnf, and the reduction of H3K27me3 results in increased trimethylation of H3K4. Our findings identify reversal of polycomb repression as a key step in gene activation after injury.

Key words: chromatin; injury; myelin; polycomb; regeneration; Schwann cell

\section{Significance Statement}

Peripheral nerve regeneration after injury is dependent upon implementation of a novel genetic program in Schwann cells that supports axonal survival and regeneration. Identifying means to enhance Schwann cell reprogramming after nerve injury could be used to foster effective remyelination in the treatment of demyelinating disorders and in identifying pathways involved in regenerative process of myelination. Although recent progress has identified transcriptional determinants of successful reprogramming of the Schwann cell transcriptome after nerve injury, our results have highlighted a novel epigenomic pathway in which reversal of the Polycomb pathway of repressive histone methylation is required for activation of a significant number of injuryinduced genes.

\section{Introduction}

The remarkable plasticity of Schwann cells underlies the extensive regenerative capacity of peripheral nerves (Kim et al., 2013; Jessen and Mirsky, 2016). After injury, Schwann cells proliferate

Received April 25, 2016; revised July 8, 2016; accepted July 15, 2016.

Author contributions: K.H.M., H.A.H., and J.S. designed research; K.H.M. and H.A.H. performed research; K.H.M. and H.A.H. contributed unpublished reagents/analytic tools; K.H.M., H.A.H., and J.S. analyzed data; K.H.M. and J.S. wrote the paper.

This work was supported by the National Institutes of Health (Grant NS075269 to J.S. and P30 Core Grant HD03352). We thank Marie Adams and the University of Wisconsin Biotechnology Center for performance and preliminary analysis of Illumina sequencing, Stuart Orkin for generously providing the Eed fl/fl mice, and Camila Lopez-Anido for bioinformatics assistance and comments on the manuscript.

The authors declare no competing financial interests.

Correspondence should be addressed to John Svaren, Waisman Center, 1500 Highland Ave., University of Wisconsin, Madison, WI 53705. E-mail: john.svaren@wisc.edu.

DOI:10.1523/JNEUROSCI.1370-16.2016

Copyright $\odot 2016$ the authors $\quad 0270-6474 / 16 / 369135-13 \$ 15.00 / 0$ and launch the transcriptional signature of immature stages with concomitant repression of myelin genes (Nagarajan et al., 2002; Patodia and Raivich, 2012a, 2012b; Kim et al., 2013; Brosius Lutz and Barres, 2014; Jessen and Mirsky, 2016), so the transition was historically viewed as dedifferentiation. However, Schwann cells in injured nerves also activate genes that are never expressed during embryonic Schwann cell development and are unique to the injury condition, such as Shh and Olig1 (Arthur-Farraj et al., 2012; Lin et al., 2015). Such changes allow Schwann cells to promote axon regeneration and therefore have been termed "repair" Schwann cells. For example, although dispensable in differentiation, the injury-induced transcriptional factor c-Jun was highlighted as a critical regulator of the repair process (Arthur-Farraj et al., 2012). Nerves with c-Jun-deficient Schwann cells displayed delayed demyelination, greater neuronal death, reduced macrophage migration and myelin clearance, and failure of reinnervation and functional recovery. These observations reflect the 
Table 1. Primer sequences used for qRT-PCR and ChIP-qPCR experiments

\begin{tabular}{|c|c|}
\hline \multicolumn{2}{|c|}{ Rat qRT-PCR primer sequence } \\
\hline \multicolumn{2}{|l|}{$\operatorname{lgfbp} 2$} \\
\hline Forward & сCCCCAGTGGCAGTTAACCT \\
\hline Reverse & CAGTGCCACCACCCTCTCTATTA \\
\hline \multicolumn{2}{|l|}{ Thy1 } \\
\hline Forward & TACTCTAGCCAACTTCACCACCAA \\
\hline Reverse & GCCCGAGACTCGAAGTTCAC \\
\hline \multicolumn{2}{|l|}{ Esm1 } \\
\hline Forward & GCTGATCCTGGCTGAGATTTG \\
\hline Reverse & TGTTGGCTGAAAGTTGGTCACT \\
\hline \multicolumn{2}{|l|}{ Shh } \\
\hline Forward & GCGGGCATCCACTGGTACT \\
\hline Reverse & TCGGACTTCAGCTGGACTTGA \\
\hline \multicolumn{2}{|l|}{ Fgf5 } \\
\hline Forward & GGGCTGGGTGGCTTTTTC \\
\hline Reverse & CGAGCAACCGGAACTTTCC \\
\hline \multicolumn{2}{|l|}{ Vegfa } \\
\hline Forward & AATCCAGAAAGCCTGACATGAAG \\
\hline Reverse & GCCCTCCGGACCCAAA \\
\hline \multicolumn{2}{|l|}{ Vgf } \\
\hline Forward & ТСТССТCСССТСTTCGATGAT \\
\hline Reverse & TAGTCTCATTGAACTGTCCACCAAAC \\
\hline \multicolumn{2}{|l|}{ Gdnf } \\
\hline Forward & ACTGACTTGGGTTTGGGCTA \\
\hline Reverse & СCTGGCCTACCTTGTCACTT \\
\hline \multicolumn{2}{|l|}{ Mmp13 } \\
\hline Forward & CTGGAACCACATTGAAGAATTGTAA \\
\hline Reverse & GCACCCAAGAATCAGGTGATC \\
\hline \multicolumn{2}{|l|}{$\mathrm{CxCl} 2$} \\
\hline Forward & TTCCTGGGTGCAGTTCGTTT \\
\hline Reverse & CATGGGCTCCTGTACCTCAAC \\
\hline \multicolumn{2}{|l|}{ Foxq1 } \\
\hline Forward & GTAGCTGCCCCGGAAAAAG \\
\hline Reverse & ACGCTGGCCGAGATCAAC \\
\hline \multicolumn{2}{|l|}{ Parvb } \\
\hline Forward & GTCCACTCTGCGGGTCCTT \\
\hline Reverse & GCTCTGTCACTCGACGTCCTT \\
\hline \multicolumn{2}{|l|}{ Runx2 } \\
\hline Forward & CCGTAGAGAGCAGGGAAGACA \\
\hline Reverse & ACGATGGCAGACACCAACTG \\
\hline \multicolumn{2}{|l|}{ Hmga2 } \\
\hline Forward & GGAAATGGCCACAACAAATTG \\
\hline Reverse & CGGACTCTTGCGAGGATGTC \\
\hline \multicolumn{2}{|c|}{ Mouse qRT-PCR primer sequence } \\
\hline $\operatorname{lgfbp} 2$ & \\
\hline Forward & GCGGGTACCTGTGAAAAGAG \\
\hline Reverse & CCTCAGAGTGGTCGTCATCA \\
\hline Runx2 & \\
\hline Forward & ACCAAGTAGCCAGGTTCAAC \\
\hline Reverse & GAGGATTTGTGAAGACTGTTATGG \\
\hline Olig1 & \\
\hline Forward & AGCGATGTAGTTGCTTGGGAT \\
\hline Reverse & CTGGCTCTAAACAGGTGGGAT \\
\hline Pou3f1/Scip & \\
\hline Forward & CTGAGCTTCAAGAACATGTGCAA \\
\hline Reverse & GCGATCTTGTCCAGGTTGGT \\
\hline Mmp13 & \\
\hline Forward & ACCTGATTCTTGCGTGCTATGA \\
\hline Reverse & GCAGATGGACCCCATGTTTG \\
\hline Thy1 & \\
\hline Forward & TTCCTCCCTGCCAACCAA \\
\hline Reverse & GCACAGTCCAACTTCCCTCATC \\
\hline Bdnf & \\
\hline Forward & GGTATCCAAAGGCCAACTGA \\
\hline Reverse & $\begin{array}{l}\text { GCAGCCTTCCTTGGTGTAAC } \\
\text { (Table Continues) }\end{array}$ \\
\hline
\end{tabular}

Table 1. Continued

\begin{tabular}{|c|c|}
\hline \multicolumn{2}{|l|}{ Hmga2 } \\
\hline Forward & CAAGAGGCAGACCTAGGAAATG \\
\hline Reverse & СTCTTGCGAGGATGTCTCTTC \\
\hline \multicolumn{2}{|l|}{ Wif1 } \\
\hline Forward & ACCCCTACCCCACCATCTG \\
\hline Reverse & CACGCGAAAGGTTAACAAAGG \\
\hline \multicolumn{2}{|l|}{ Esm1 } \\
\hline Forward & GAAATGGTTAAATCCACGCTGAT \\
\hline Reverse & GGTCACTAAAATGGAGCCTTCTCT \\
\hline \multicolumn{2}{|l|}{ Fgf5 } \\
\hline Forward & AAAAGCCACCGGTGAAACC \\
\hline Reverse & TCACTGGGCTGGGACTTCTG \\
\hline \multicolumn{2}{|l|}{ Shh } \\
\hline Forward & СAGCGACTTCCTCACCTTCCT \\
\hline Reverse & AGCGTCTCGATCACGTAGAAGAC \\
\hline \multicolumn{2}{|l|}{ Gdnf } \\
\hline Forward & TCTCGAGCAGGTTCGAATGG \\
\hline Reverse & AAGAACCGTCGCAAACTTTACC \\
\hline \multicolumn{2}{|r|}{ (2) } \\
\hline Forward & GACTGTGGAGATGGGGGATGGTGA \\
\hline Reverse & GTGCTGGTGTGGGTGGGAACTGAG \\
\hline \multicolumn{2}{|l|}{ Vgf } \\
\hline Forward & ТСТССТССАССTCTTCGATGAT \\
\hline Reverse & TAGTCTCATTGAACTGTCCACCAAAC \\
\hline \multicolumn{2}{|c|}{ Rat ChIP-qPCR primer sequence } \\
\hline \multicolumn{2}{|c|}{$\operatorname{lgfbp2}$} \\
\hline Forward & CACAGCAAGTTGCAGGTAATGC \\
\hline Reverse & CCCGCTGAGCTACGAGTTTC \\
\hline \multicolumn{2}{|l|}{ Runx2 } \\
\hline Forward & САССССТTСАТСТСТСААССА \\
\hline Reverse & TTGTTTCCCGGCGTTTTG \\
\hline \multicolumn{2}{|l|}{ Thy1 } \\
\hline Forward & GGCAATGGTGGATAGAAAGCA \\
\hline Reverse & CCGTGAGTACTCTCCCATTTGG \\
\hline \multicolumn{2}{|l|}{ Bdnf } \\
\hline Forward & TGAAAAACGGGCAGTTGGA \\
\hline Reverse & TCCCTTTGTGTGGCGAACA \\
\hline \multicolumn{2}{|l|}{ Hmga2 (1) } \\
\hline Forward & ACTGTGCGGTCAGAAAGCAA \\
\hline Reverse & GCTGAGTGCCCCACTGGAT \\
\hline \multicolumn{2}{|l|}{ Hmga2 (2) } \\
\hline Forward & GGAAAGACACATCTGTGCAGACA \\
\hline Reverse & TTTTCGGAGCCCACGGTAT \\
\hline \multicolumn{2}{|l|}{ Esm1 (1) } \\
\hline Forward & AAGCAGCCTGCGTTGCA \\
\hline Reverse & CCGCAGCGCACACTTG \\
\hline Shh & \\
\hline Forward & ССССАСССССACTTTTG \\
\hline Reverse & GTCATTCTGGTTCCCAACACAA \\
\hline Fgf5 & \\
\hline Forward & CGGCCAGGGCATTCTAGAA \\
\hline Reverse & GGTAGCAGGCATGGCTAACC \\
\hline Gdnf & \\
\hline Forward & GCGGGCGACTGAGTGTAAAG \\
\hline Reverse & GCCTCCCTCCGGTTCAAC \\
\hline $\operatorname{Vgf}(1)$ & \\
\hline Forward & CATTGCCGCATAGATGAGTCA \\
\hline Reverse & CAATTAGCTGTCTCTCGGTGTCTCT \\
\hline $\operatorname{Vgf}(2)$ & \\
\hline Forward & ACGCCCAAGGACGACTTG \\
\hline Reverse & CCCACACCGCAGATCCA \\
\hline Foxq1 & \\
\hline Forward & GACCGCTCCTGCGTCTTTC \\
\hline Reverse & $\begin{array}{l}\text { CCAGCGGAGGACAACCTTAC } \\
\text { (Table Continues) }\end{array}$ \\
\hline
\end{tabular}


Table 1. Continued

\begin{tabular}{|c|c|}
\hline Sqle & \\
\hline Forward & САCCCCTCTGCCCAGTACA \\
\hline Reverse & САСАСТTCTTCATTCAGCCAACTAA \\
\hline $\begin{array}{l}\text { Mouse ChIP-qPC } \\
\text { lgfbp2 }\end{array}$ & \\
\hline Forward & CCGCTAGCTCGCTGCACTA \\
\hline Reverse & CCAATCTCGGCAGCATGTT \\
\hline Runx2 & \\
\hline Forward & GTTGTTTGCGCCTCTTTGC \\
\hline Reverse & AGCACAGCGATCCACTTTTTG \\
\hline Thy1 & \\
\hline Forward & TTTCCCTCAGCCTCCGATT \\
\hline Reverse & GCTGAAGCCCGCAGTTTTC \\
\hline Bdnf & \\
\hline Forward & GGGAAGACCTCTCCACACTCTTAC \\
\hline Reverse & AGCTCCTGGCCTGAACAAAG \\
\hline Hmga2 & \\
\hline Forward & GGGTTGCTCTCTCCGCAAA \\
\hline Reverse & GGGACACAATTCACTCCAAGTCT \\
\hline Esm1 & \\
\hline Forward & GCTGACCACACTCCTGGTACCT \\
\hline Reverse & GCAATCCACCGCATATTTGG \\
\hline Fgf5 & \\
\hline Forward & TGCGGGTGCTGGGTAAA \\
\hline Reverse & CCGTCCTCTGTGGTCACATG \\
\hline $\operatorname{Shh}(\mathrm{H} 3 \mathrm{~K} 27 \mathrm{n}$ & \\
\hline Forward & GGAAGCGCAGACAGACACTCT \\
\hline Reverse & CACAACAGCCTGGCACTCTCT \\
\hline Shh (H3K4m & \\
\hline Forward & GGTAGCAAGGCTGGAGAGCTT \\
\hline Reverse & CGCCCCTGCCAGCTATAATA \\
\hline Gdnf & \\
\hline Forward & CCCCTGGATTGCGTGCTC \\
\hline Reverse & GGACATTAACTCCAAGTGGCCC \\
\hline Vgf & \\
\hline Forward & ССТTССССТTТСААСССТTA \\
\hline Reverse & GGGCGCCAGTAAAAGATCAG \\
\hline Sqle & \\
\hline Forward & CCTGTAGCTCTCTTGCGTTTGA \\
\hline Reverse & GCTCGCTCTGGAGGAACTCTT \\
\hline Tekt3 & \\
\hline Forward & GCCTTGGAATGGATAGGGAGTT \\
\hline Reverse & GATAGCGGGTGTTGGGAGACT \\
\hline
\end{tabular}

importance of the functional repair Schwann cells in nerve regeneration and other studies have shown that aging-associated impairment of peripheral nerve regeneration is due to deficient Schwann cell responses (Verdú et al., 2000; Kang and Lichtman, 2013; Painter et al., 2014).

Epigenomic regulation is an important aspect of genetic reprogramming in differentiation of diverse cell lineages. The roles of several epigenomic modulators have been characterized in Schwann cell differentiation and myelination (Chen et al., 2011; Jacob et al., 2011; Hung et al., 2012; Weider et al., 2012; Ma et al., 2015), but the injury-induced epigenomic reprograming that leads to the activation of genes involved in the nerve repair program has not been characterized.

Polycomb Repressive Complex 2 (PRC2) represses target genes through dimethylation and trimethylation of histone $\mathrm{H} 3$ Lys27 (H3K27me2 and H3K27me3; Pasini et al., 2004; Montgomery et al., 2005; Boyer et al., 2006; Ezhkova et al., 2009; Ezhkova et al., 2011; Aldiri and Vetter, 2012). The complex consists of EZH2, with methyltransferase activity, and the nonredundant core subunits, suppressor of zeste 12 (SUZ12) and embryonic ectoderm development (EED). H3K27 methylation represses transcription by recruiting other factors such as PRC1, which in turn catalyzes ubiquitination of $\mathrm{H} 2 \mathrm{~A}$, blocking transcriptional elongation, and RBP2 demethylase, which reverses the trimethylation of H3 Lys4 (H3K4me3), a modification associated with active promoters (Viré et al., 2006; Mikkelsen et al., 2007; Stock et al., 2007; Ku et al., 2008; Pasini et al., 2008; Blackledge et al., 2015).

As a first step in understanding the role of the polycomb pathway and H3K27 trimethylation in peripheral nerves, we analyzed a Schwann-cell-specific deletion of the Eed (Eed cKO) subunit of the PRC2 complex. Early development of myelin was largely unaffected, but older mice developed progressive hypermyelination and morphological changes affecting both myelinated and unmyelinated nerve fibers of adult nerves (Ma et al., 2015). Interestingly, loss of $\mathrm{H} 3 \mathrm{~K} 27 \mathrm{me} 3$ caused an induction of a number of repressed genes and, in particular, $30 \%$ of derepressed genes were a subset of genes that are normally upregulated after peripheral nerve injury. This included the Sonic hedgehog (Shh) gene, which is not normally expressed in Schwann cells, but is activated upon nerve injury (Arthur-Farraj et al., 2012; Lin et al., 2015). Because depletion of H3K27me3 was sufficient for the activation of a number of injury-induced genes in Schwann cells, removal of $\mathrm{H} 3 \mathrm{~K} 27 \mathrm{me} 3$ may be required in conjunction with injury-induced transcription factors to activate a larger subset of injury response genes. The results described below indicate how injury genes are normally repressed before injury and describe the epigenetic changes that are involved in reprogramming Schwann cells after nerve injury.

\section{Materials and Methods}

Primer sequences and antibodies. The antibodies targeting H3K27me3 (Active Motif, 39155), H3K27ac (Active Motif, 39133), and H3K4me3 (Millipore, 04-745) were used in the study. Primers are listed in Table 1.

Experimental animals and nerve injury surgery. All animal experiments were performed according to protocols approved by the University of Wisconsin Graduate School. Eed-floxed mice were generated by backcrossing the flox allele for seven generations against the C57BL/6 genetic background and mated to mP0TOTA-Cre [B6N.FVB-Tg(Mpzcre)26Mes/J; Jackson Laboratory]. Mice were genotyped as described previously (Feltri et al., 1999; Xie et al., 2014). Samples collected from mice homozygous for floxed Eed served as control in this study. Sciatic nerves of adult Sprague Dawley rats or mice were cut by following the surgery protocol described previously (Hung et al., 2015). As a control, the contralateral limb also received a sham operation consisting of only a skin incision. The nerve tissue distal to the transection and contralateral (sham) nerves were isolated for use in gene expression analysis and ChIP experiments. Both male and female mice were used individually per sample at a similar ratio between the floxed Eed and Eed cKO genotypes of gene expression analysis and ChIP experiments. Male rats were used in ChIP experiments after nerve injury surgery.

Nerve explant cultures. Adult male Sprague Dawley rat sciatic nerves were cut into $3 \mathrm{~mm}$ segments and cultured in serum-free RPMI-1640 medium supplemented with penicillin/streptomycin in the presence of GSK-J4 (Tocris Bioscience, 4594 ) or DMSO at $37^{\circ} \mathrm{C}$ for 1 or $3 \mathrm{~d}$.

$q R T-P C R$. RNA was isolated from sciatic nerves using RNeasy Lipid Tissue Mini Kit (Qiagen) according to the manufacturer's directions. To prepare cDNA, $250 \mathrm{ng}$ or $1 \mu \mathrm{g}$ of total RNA of mouse or rat nerves, respectively, was used from each sample. qRT-PCR and data analysis were performed as described previously (Hung et al., 2012). Statistical analyses were evaluated by one-way ANOVA.

In vivo ChIP. Sciatic nerves were subjected to ChIP with antiH3K27me3 and anti-H3K27 acetylation antibodies as described previously (Hung et al., 2015).

Micrococcal nuclease (MNase)-aided in vivo ChIP. Sciatic nerves were subjected to MNase-ChIP with anti-H3K4me3 antibody as described previously with minor modifications (Ma et al., 2015). After incubation 
A
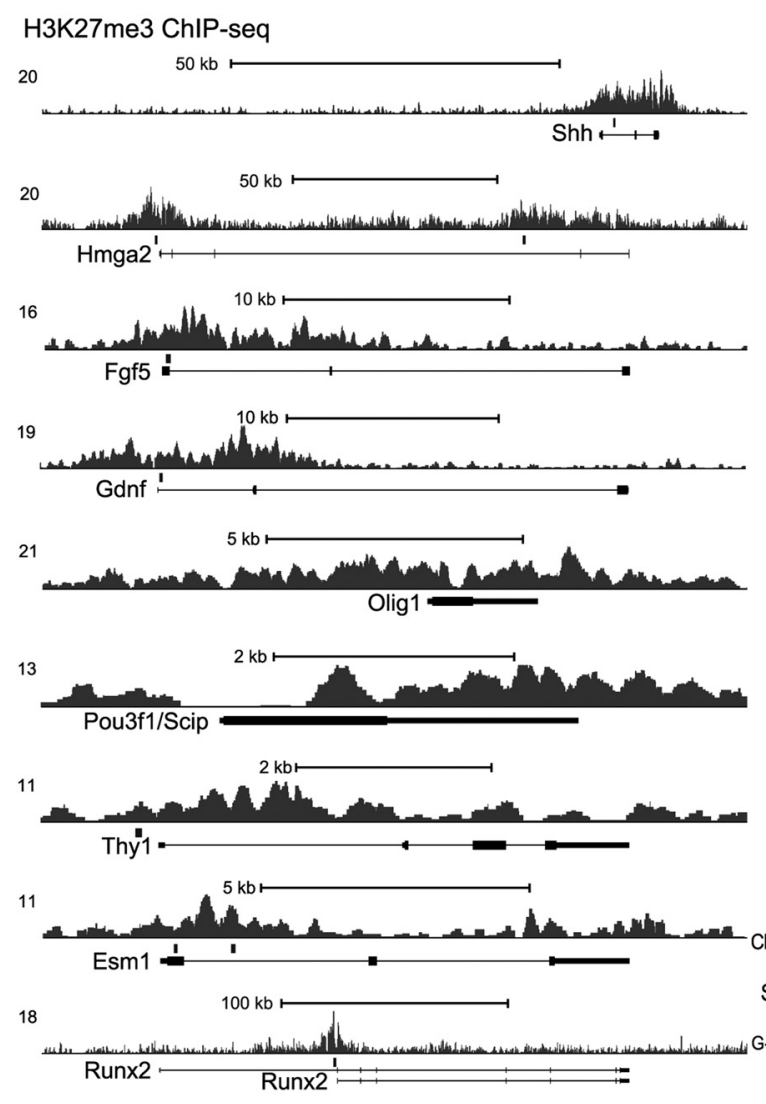

14

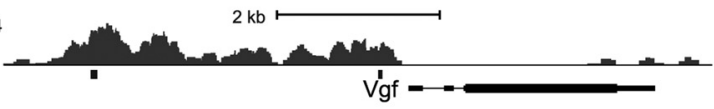

14
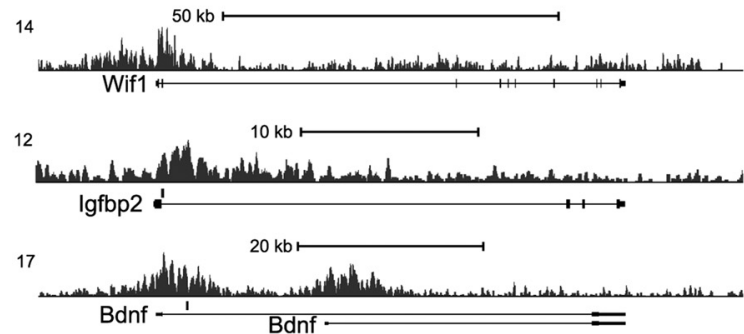

B

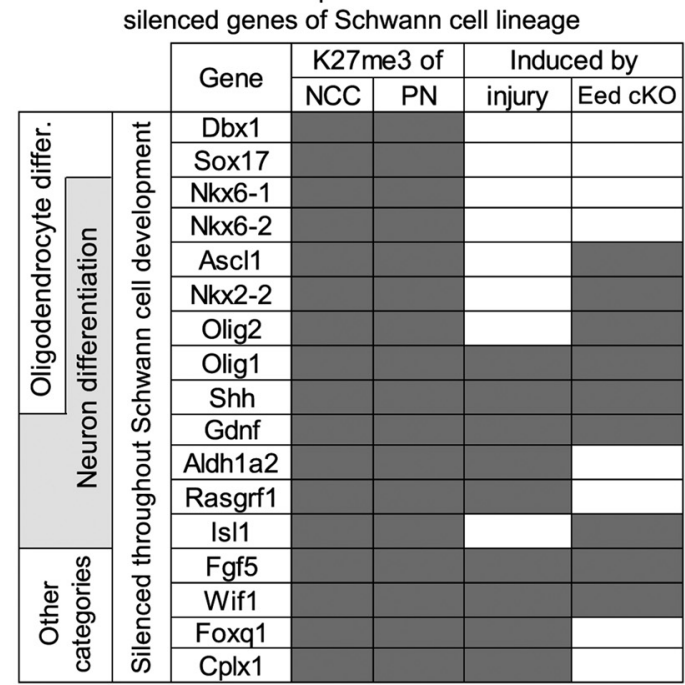

C

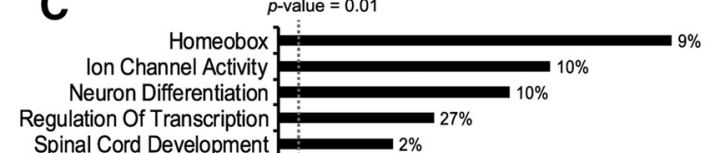

Tube Development $15 \%$

Tube Devo

$6 \%$
Neuron Projection

Skeletal System Development $6 \%$

Eye Development $12 \%$

G-Protein Coupled Receptor Signaling $12 \%$

Heart Development $4 \%$

Epithelium Development $4 \%$

Mesenchymal Cell Differentiation $2 \%$

Kidney Development $2 \%$

Gliogenesis $2 \%$

Immune System Development $3 \%$

Oligodendrocyte Differentiation $1 \%$

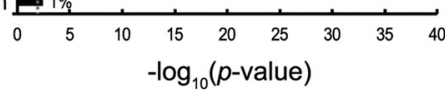

$-\log _{10}(p$-value $)$

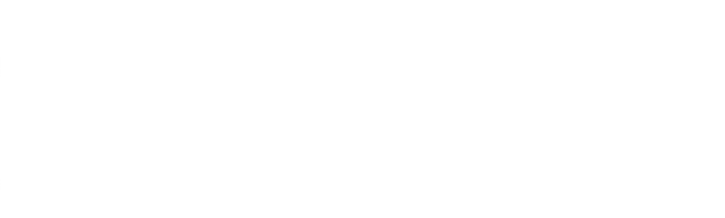

Figure 1. Analysis of H3K27me3-occupied genes in peripheral nerve. A, ChIP-seq mapping of H3K27me3 was performed in intact rat sciatic nerve. The transcription start site (TSS) is on the left. The locations of primer sets used in the ChIP-qPCR analysis (Fig. 4) are indicated with gray rectangles above the gene bodies. $\boldsymbol{B}$, Representative genes with H3K27me3 that are not detectably expressed in expression profiles of human neural crest and mouse embryonic Schwann cells are listed (Buchstaller et al., 2004; Rada-Iglesias et al., 2012). Gray fillings indicate H3K27me3 occupancy of genes in NCCs and peripheral nerves (PNs), with postinjury induction $\geq 5$-fold, and genes tested by qRT-PCR analysis and identified derepressed by the Schwann-cell-specific deletion of Eed (Eed CK0) compared with control, with $p<0.05$. Injury-induced genes were identified from microarray analysis of peripheral nerves 1, 3, or $7 \mathrm{~d}$ after injury (Barrette et al., 2010; Arthur-Farraj et al., 2012; Kim et al., 2012). Other injury-induced genes that are associated with H3K27me3 and are not detectably expressed in neural crest/embryonic Schwann cells are as follows: Pcdh20, Gch1, Runx2, Runx1, TIr2, Ikzf1, Irf8, Nptx1, SIc32a1, Arhgap9, Fosl1, II10ra, Mcoln3, and C1qI2. C, Enriched gene ontology categories for the silenced genes in Schwann cell lineage with H3K27me3 present at NCC and peripheral nerves. Categories with $p<0.01$ are listed.

with Dynabeads Protein G (Invitrogen, 10004D), ChIP samples were washed once with washing buffer 1 (WB1; containing $50 \mathrm{~mm}$ Tris- $\mathrm{HCl}$, $\mathrm{pH} 7.5,10 \mathrm{~mm}$ EDTA, and $125 \mathrm{~mm} \mathrm{NaCl}$ ), once with WB2 (containing 50 mM Tris- $\mathrm{HCl}, \mathrm{pH} 7.5,10 \mathrm{~mm}$ EDTA, and $250 \mathrm{~mm} \mathrm{NaCl}$ ), and twice with WB3 (containing $50 \mathrm{~mm}$ Tris- $\mathrm{HCl}$, pH 7.5, $10 \mathrm{~mm}$ EDTA, and $500 \mathrm{~mm}$ $\mathrm{NaCl}$ ). The samples were then eluted at $65^{\circ} \mathrm{C}$ with elution buffer containing $50 \mathrm{~mm} \mathrm{NaCl}, 50 \mathrm{~mm}$ Tris- $\mathrm{HCl}, \mathrm{pH}$ 7.5, 5 mm EDTA, and 1\% SDS for 15 min. DNA was purified by phenol chloroform extraction and subjected to qPCR or sequencing. Statistical analyses were evaluated by oneway ANOVA.

ChIP-seq. Library preparation and sequencing was performed by the University of Wisconsin Biotechnology Center as described previously (Hung et al., 2015). Base calling was performed using the standard Illumina Pipeline. Reads were mapped to the Rattus norvegicus genome rn5 using Bowtie to produce SAM files for further analysis. From the two biological replicates, $14,043,249$ and 27,142,309 reads were obtained in input samples, 25,903,222 and 20,923,482 reads in H3K27me3 ChIP samples, 11,943,112 and 10,652,537 reads in H3K4me3 samples (Sham), and 8,034,552 and $13,272,596$ in H3K4me3 samples (cut). Hypergeometric optimization of motif enrichment (HOMER; Heinz et al., 2010) was used to determine enriched binding regions for $\mathrm{H} 3 \mathrm{~K} 27 \mathrm{me} 3-\mathrm{ChIP}$ relative to sequencing of an input chromatin sample. The raw data files are deposited in National Center for Biotechnology Information Gene Expression Omnibus under accession numbers GSE84265 and GSE84272. 
Bioinformatic analysis. K27me3-occupied genes were defined by the presence of $\mathrm{H} 3 \mathrm{~K} 27 \mathrm{me} 3$ around the transcriptional start site $( \pm 7 \mathrm{~Kb})$ with a HOMER peak score $\geq 10$. A previous microarray analysis of embryonic Schwann cell development [neural crest to postnatal day 0 (P0)] was used to identify expressed genes, which were called present on the majority of replicate expression arrays for at least one developmental stage by Buchstaller et al. (2004). We also used neural crest cell (NCC) RNA-seq analysis by Rada-Iglesias et al. (2012) to identify nonexpressed gene (Reads Per Kilobase of transcript per Million mapped reads $[\mathrm{RPKM}]<1.5)$. Nonexpressed genes in both experiments were designated as the silenced genes in Schwann cell lineage. Genes with RPKM $\geq 1.5$ of the NCC RNA-seq analysis were referred to as NCC genes. Genes with fold reduction $\geq 2$ of any embryonic time points from embryonic day 9.5 (E9.5) relative to P0 (Buchstaller et al., 2004) and between P0 and P56, the time point of myelination at maturity identified by Verdier et al. (2012), were identified as downregulated genes of embryonic and postnatal Schwann cells, respectively. Gene ontology analysis was performed using Database for Annotation, Visualization, and Integrated Discovery (DAVID; da Huang et al., 2009a, 2009b).

\section{Results}

In our previous study, we found that depletion of $\mathrm{H} 3 \mathrm{~K} 27 \mathrm{me} 3$ by a Schwann-cell-specific deletion of a PRC2 component, Eed, leads to derepression of a group of genes that are normally expressed after injury (Ma et al., 2015). This suggested that the removal of this repressive histone modification is a critical step for the activation of a subset of injury response genes in Schwann cell repair program. To understand the role of H3K27 trimethylation in gene repression before injury, we first generated a genome-wide map of $\mathrm{H} 3 \mathrm{~K} 27 \mathrm{me} 3$ in mature rat sciatic nerve. The ChIP-seq analysis revealed 2622 H3K27me3-occupied genes of peripheral nerves that have $\mathrm{H} 3 \mathrm{~K} 27 \mathrm{me} 3$ peaks within gene bodies (Shh, Hmga2, Fgf5, and Gdnf) and/or at promoters (Runx2 and $\mathrm{Vgf}$ ) (Fig. 1A). Approximately $10 \%$ of $\mathrm{H} 3 \mathrm{~K} 27 \mathrm{me} 3$-associated genes become induced $\geq 2$-fold after nerve injury.

Two genes that promote axonal survival and regeneration after injury are Gdnf and Shh (Oppenheim et al., 1995; Yan et al., 1995; Boyd and Gordon, 2003; Hashimoto et al., 2008; Fontana et al., 2012; Martinez et al., 2015). A recent study found that Sonic hedgehog is not expressed at any stage of Schwann development before its de novo induction after injury (Lin et al., 2015). Therefore, we also analyzed the genes associated with $\mathrm{H} 3 \mathrm{~K} 27 \mathrm{me} 3 \mathrm{com}-$ pared with the H3K27me3-map of human NCCs (Rada-Iglesias et al., 2012) and performed a comparison analysis. Approximately $30 \%$ of peripheral nerve $\mathrm{H} 3 \mathrm{~K} 27 \mathrm{me} 3$-associated genes are silenced and occupied with H3K27me3 in NCCs (Rada-Iglesias et al., 2012). Many of these genes are not detectably expressed in microarray analysis of embryonic Schwann cell development (Buchstaller et al., 2004) and some were induced in Eed-deficient Schwann cells, including Nkx2-2, Olig1, Wif1, and Fgf5 (see Fig. $6 B$; Ma et al., 2015). The comparison analysis of H3K27me3-map of peripheral nerves and NCC suggests that the mark was established at an early stage of Schwann cell development and representative genes of this type are shown in Figure 1B. Gene ontology analysis was used to characterize $\mathrm{H} 3 \mathrm{~K} 27 \mathrm{me} 3$-occupied genes (Fig. 1C). Consistent with previous studies, many homeobox genes are subject to polycomb silencing (Schwarz et al., 2014). Another large group of these silenced genes are specifically associated with neuron differentiation and another subset (including Ascl1, Nkx2-2, Olig1, Olig2, and Shh) are also critical regulators of oligodendrocyte differentiation and gliogenesis (Orentas et al., 1999; Fogarty et al., 2005; Vallstedt et al., 2005; Fig. 1 B, C).

Discovering injury-induced genes such as Sonic hedgehog is important because these appear to be unique markers of the repair Schwann cell phenotype (Jessen and Mirsky, 2016). If one
A

\section{Genes with post-injury induction $\geq 5$-fold}
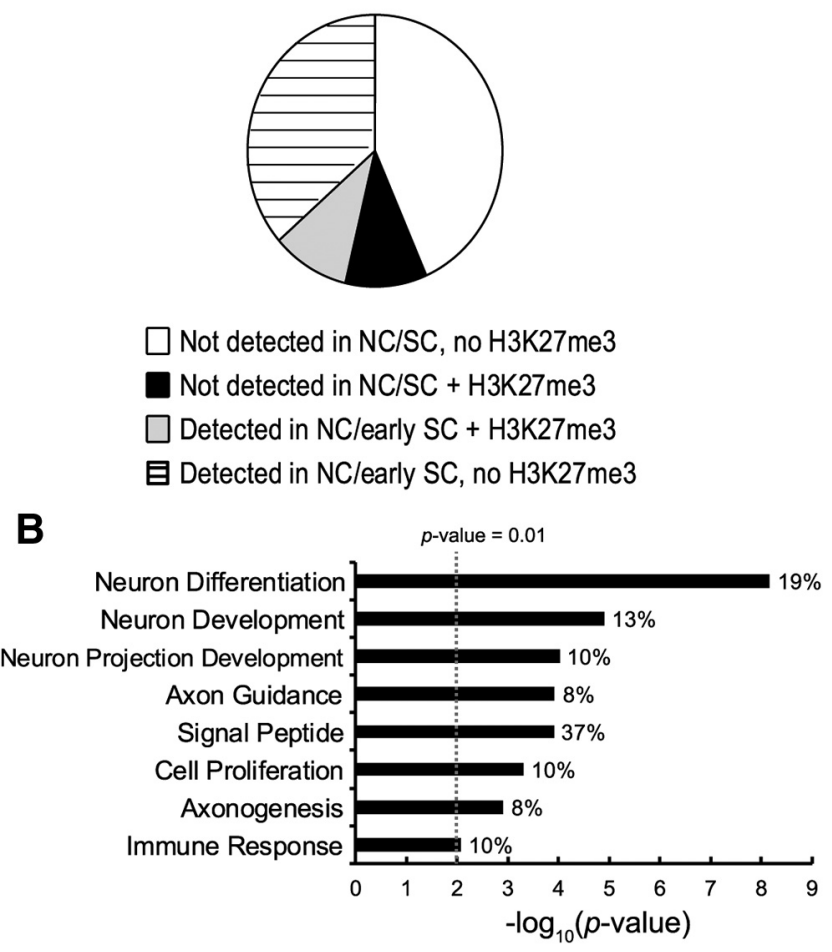

Figure 2. H3K27me3-occupied injury-activated genes are involved with critical roles of repair Schwann cells. A, Injury-induced genes (Barrette et al., 2010; Arthur-Farraj et al., 2012; Kim et al., 2012) were divided by their embryonic expression and the presence of $\mathrm{H} 3 \mathrm{~K} 27 \mathrm{me} 3$ around the transcription start site $( \pm 7 \mathrm{~Kb})$. The expression is determined by RNA-seq analysis of human NCCs (Rada-Iglesias et al., 2012) and microarray analysis of embryonic Schwann cell (SC) development (Buchstaller et al., 2004). B, Enriched gene ontology categories for H3K27me3occupied genes with postinjury induction $\geq 5$-fold. Categories with $p$-value $<0.01$ are listed.

assumes that repression by $\mathrm{H} 3 \mathrm{~K} 27 \mathrm{me} 3$ in neural crest is a feature of such genes, our results identify a number of other candidate markers that may uniquely mark the repair Schwann cell phenotype in mature nerves. For example, both Gdnf and Fgf5 are highly induced in Schwann cells after nerve injury. Altogether, we identify $\sim 24 \mathrm{H} 3 \mathrm{~K} 27 \mathrm{me} 3$-occupied genes that are silenced in NCC and then become strongly activated (induction $\geq 5$-fold) in Schwann cells after nerve injury, including Olig1, Shh, Gdnf, Aldh1a2, Rasgrf1, Fgf5, Wif1, Foxq1, and Cplx1 (examples listed in Fig. $1 B$ ). However, it should be noted that, in contrast to microarray data, Gdnf expression has been detected in embryonic Schwann cells (Piirsoo et al., 2010).

Using previous microarray analysis of embryonic and postnatal Schwann cell development (Buchstaller et al., 2004; Verdier et al., 2012), we found that $\sim 8 \%$ of H3K27me3-occupied genes are expressed in embryonic and/or promyelinating stages, but then are downregulated before mature myelination (reduction $\geq 2$ fold), including genes that were induced in Eed-deficient peripheral nerve, such as Igfbp2, Pax3, Hmga2, Tbx2, and Pou3f1/Scip (see Fig. 6B; Ma et al., 2015). Many of these genes lacked $\mathrm{H} 3 \mathrm{~K} 27 \mathrm{me} 3$ in NCCs and therefore likely gain the mark at later stages of Schwann cell development. This analysis suggests that the polycomb pathway plays a role in Schwann cell fate determination by silencing genes of other lineages, particularly neuronal and oligodendrocyte transcriptional regulators, and in Schwann cell differentiation by downregulating genes that are expressed in embryonic and promyelinating stages of development. 
Polycomb-repressed genes can be activated by $\mathrm{H} 3 \mathrm{~K} 27$ demethylases (Agger et al., 2007; Blackledge et al., 2015). We supposed that injury-activated genes regulated by an epigenetic on-off switch may have silenced or a low basal level expression and therefore likely show a high induction after injury ( $\geq 5$-fold). H3K27me3-occupied genes constituted $\sim 20 \%$ of the more highly induced nerve injury genes (Fig. 2A) and the gene ontology analysis indicated that known functions of injury-induced genes associated with $\mathrm{H} 3 \mathrm{~K} 27 \mathrm{me} 3$ were particularly associated with the important roles of Schwann cells in injury responses, such as secreted/membrane proteins (signal peptides, e.g., Fgf5, Gdnf, and Shh), immune responses (Tlr2), guiding axons/axonogenesis and promoting neuronal development (e.g., Ngfr and Nrcam) (Fig. 2B). The latter categories include Shh and Gdnf, which provide axon guidance cues and promote axonal regeneration and neuronal survival after injury (Hashimoto et al., 2008; Schuster et al., 2010; Fontana et al., 2012; Martinez et al., 2015), representing such repair Schwann cell genes with $\mathrm{H} 3 \mathrm{~K} 27 \mathrm{me} 3$ that play critical roles in nerve regeneration.

\section{Defining the repression state of injury-activated genes}

We have previously identified injury-induced enhancers by performing ChIP-seq for H3K27acetylation before and after nerve injury and found that these enhancers were generally enriched with motifs of injury-induced transcription factors such as c-Jun and Runx2 (Hung et al., 2015). We supposed that the injuryinduced enhancers may be marked or poised for activation after injury. Previous studies have characterized developmentally poised enhancers as those that have open chromatin, histone $\mathrm{H} 3 \mathrm{~K} 4$ monomethylation, and binding of histone acetylases CBP/ p300, yet are occupied by the repressive H3K27me3 rather than H3K27 acetylation (Rada-Iglesias et al., 2011; Rada-Iglesias et al., 2012; Calo and Wysocka, 2013). In contrast, actively engaged enhancers are marked by $\mathrm{H} 3 \mathrm{~K} 27$ acetylation. We therefore tested the hypothesis that enhancers of injury-induced genes are in the poised state, which would prepare them for rapid activation upon injury by switching from trimethylation to acetylation of $\mathrm{H} 3 \mathrm{~K} 27$. However, our analysis found that distal enhancers that gain H3K27 acetylation after injury are almost universally not premarked by H3K27me3 (e.g., Shh; Fig. 3A). Most of the injuryinduced enhancers that gain $\mathrm{H} 3 \mathrm{~K} 27$ acetylation are distal to the promoter and the only sites in which injury induced an apparent local change from $\mathrm{H} 3 \mathrm{~K} 27$ trimethylation to acetylation were the promoter regions of a few genes, such as Hmga2, Fgf5, Gdnf, and Runx2, in which injury-induced sites of H3K27 acetylation overlap with repressive H3K27me3 before injury. Therefore, the distal enhancers of injury-activated genes are largely not preprogrammed as poised enhancers before injury.

Because H3K27me3 apparently does not repress enhancers before injury, we examined the distribution of H3K27me3 in injury-induced genes and the resulting heat map shows that the repressive histone modification is generally found in the promoter regions and/or gene bodies (Fig. 3B). Therefore, H3K27 trimethylation does not appear to be associated with en- hancers that are induced after injury, but rather proximal promoters and/or gene bodies.

\section{Loss of H3K27 trimethylation after nerve injury}

We performed nerve injury experiments to determine whether there was loss of this repressive histone mark at an early time point $(1 \mathrm{~d})$ after nerve injury. We chose $1 \mathrm{~d}$ after nerve injury to minimize contamination from immune cells, which normally infiltrate injured nerves beginning at $3 \mathrm{~d}$ after injury (Perkins and Tracey, 2000; Mueller et al., 2003). ChIP-qPCR analysis showed a reduced H3K27me3 level in injured nerves compared with sham nerves, suggesting denervation-induced demethylation of H3K27 (Fig. 4). For several of these genes, such as Shh, Gdnf, and Fgf5, Schwann-cell-specific deletion of Eed leading to depletion of $\mathrm{H} 3 \mathrm{~K} 27 \mathrm{me} 3$ was sufficient to activate their expression even in the absence of injury (see Fig. 6B).

To determine whether the demethylation is required for gene activation after injury, we used GSK-J4, which binds the catalytic pocket and inhibits both H3K27 demethylases, JMJD3 and UTX (Kruidenier et al., 2012). Unfortunately, this inhibitor has not been shown to pass the blood-brain or blood-nerve barrier. Therefore, to deliver the inhibitor effectively and control the environment of injured nerves, we used a nerve explant protocol in which some injury responses are activated upon transfer of nerves to culture (Banner and Patterson, 1994; Mårtensson et al., 2007; Shin et al., 2013; Blom et al., 2014). In this system, we observed induction of a number of injury-activated genes, including Shh, Igfbp2, Fgf5, and Gdnf, even after $24 \mathrm{~h}$ in culture. To test the importance of H3K27 demethylation, explanted sciatic nerves were cultured in the presence of either GSK-J4 or DMSO vehicle. The induction of injury-activated genes by explant could be inhibited by GSK-J4, as shown by Shh, Fgf5, Gdnf, Runx2, Hmga2, and others in a 1 or 3 d incubation (Fig. 5). As a control, another injury-induced gene that is not associated with H3K27me3, Timp1, was induced $\sim 15$-fold in explant culture, but this level was unaffected by GSK-J4 inhibition.

We used ChIP and gene expression analysis of nerves from the Schwann-cell-specific knock-out of Eed to determine whether genes are regulated by $\mathrm{H} 3 \mathrm{~K} 27 \mathrm{me} 3$. Ultrastructural analysis 


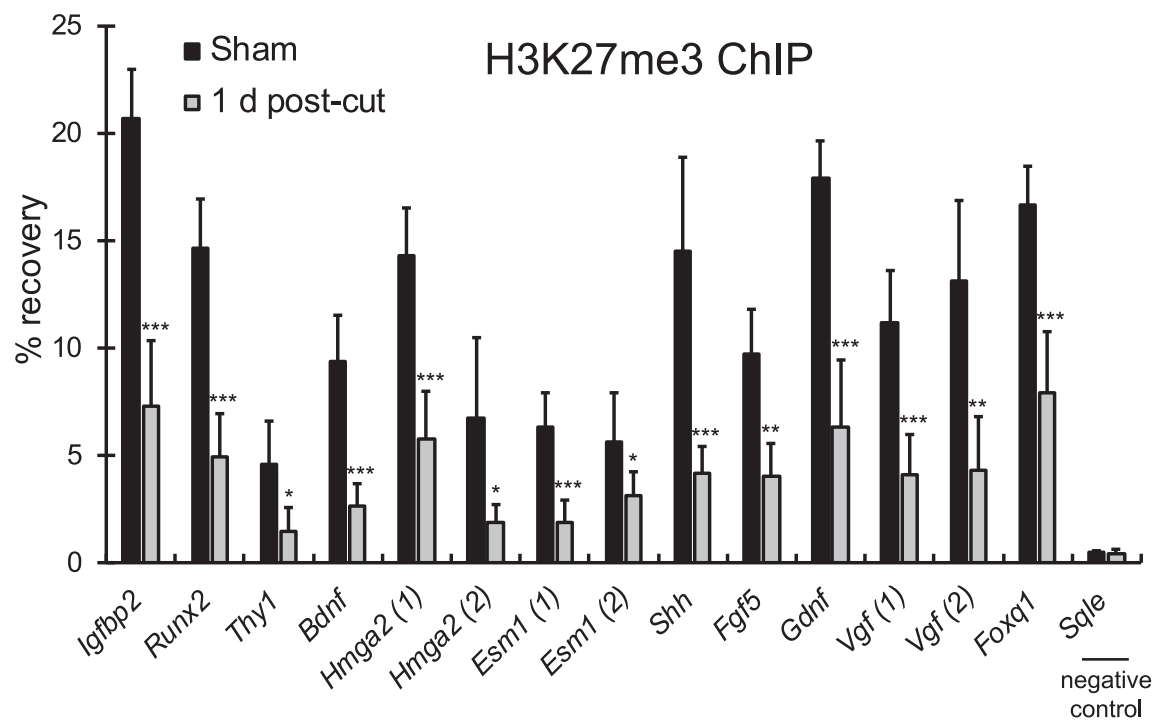

Figure 4. Injury induces demethylation of H3K27. H3K27me3-ChIP assays were performed with distal stumps of rat sciatic nerves $1 \mathrm{~d}$ after injury or sham surgery and the percentage recovery relative to input was calculated by qPCR analysis. H3K27me3bound genes identified by ChIP-seq are shown and the primer set numbers represent their location from the left. Sqle is a negative control not associated with H3K27me3. Data are shown as mean \pm SD. ${ }^{* *} p<0.005,{ }^{* * *} p<0.0005 . n=5$ for sham and $n=6$ for $1 \mathrm{~d}$ after injury. showed no apparent developmental abnormalities or pathologies that might induce injury response in Eed-deficient nerves at 2 months (Ma et al., 2015), the time point of this study. There was a significant loss of H3K27me3 at genes in Eed-deficient nerves compared with control nerves (Fig. 6A) and many of GSK-J4 affected genes were correlatively derepressed, including $\operatorname{Igfbp} 2, \mathrm{Runx2}, \mathrm{Fgf5}$, Shh, and Hmga2 (Fig. 6B). This analysis also expands our previous list of Eedregulated genes, which was obtained through microarray analysis (Ma et al., 2015), to include other injury-induced genes such as Runx2, Gdnf, Fgf5, Olig1, Pou3f1/Scip, and Bdnf. Interestingly, the promoter of $B d n f$, in particular, was recently reported as a PRC2 target in mature neurons and becomes activated upon JMJD3-mediated demethylation (Palomer et al., 2016).

Only a subset of injury-activated genes were derepressed in peripheral nerves in

A

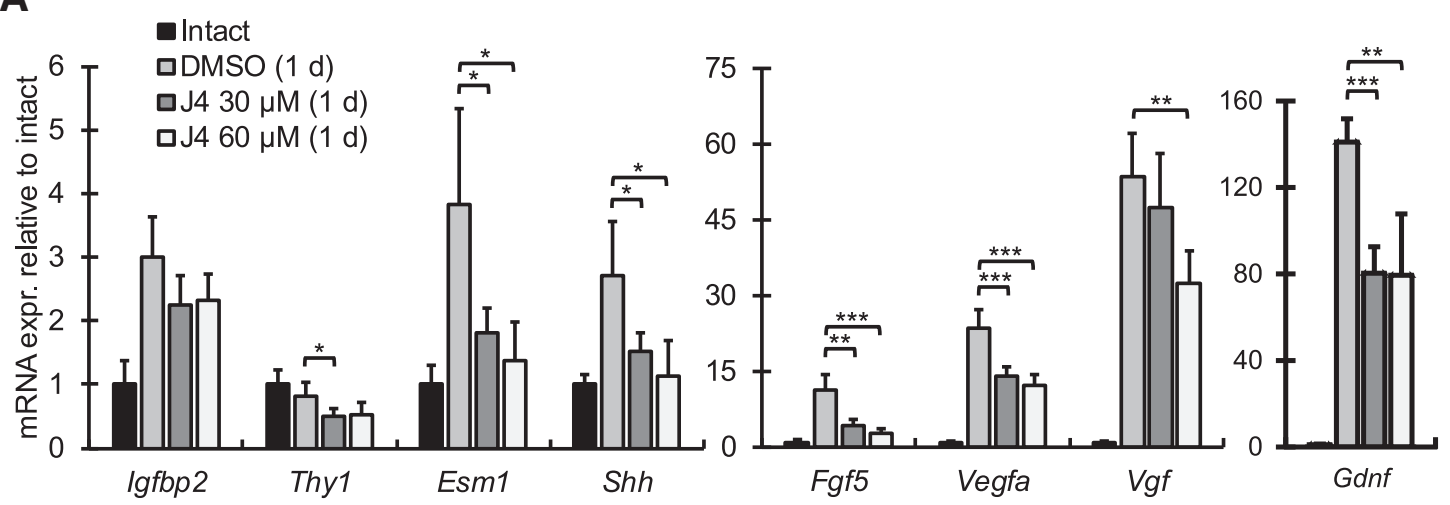

B

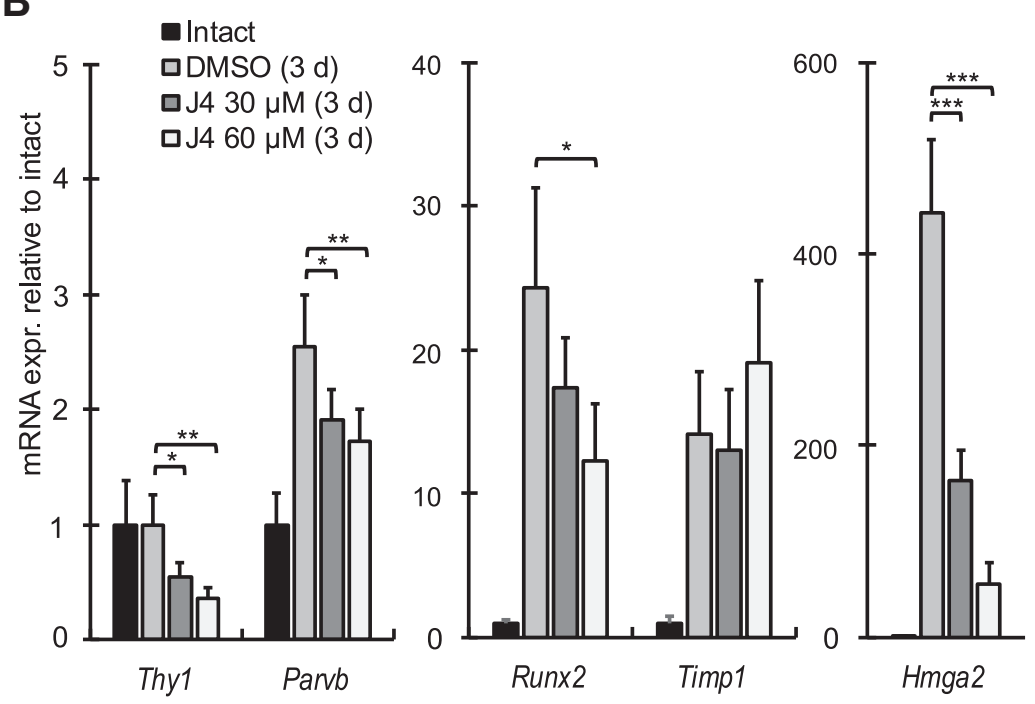

Figure 5. Inhibition of H3K27 demethylation attenuates the induction of injury-activated genes. $A, B$, Rat sciatic nerve explants were cultured for 1 or $3 \mathrm{~d}$ with the presence of GSK-J4 at indicated concentrations or DMSO vehicle and subjected to qRT-PCR together with immediately frozen nerve segments after dissection (indicated as intact). The intact level of each gene is set as 1 . Expression levels were normalized to $18 \mathrm{~S}$ rRNA. Data are shown as mean $\pm \mathrm{SD} .{ }^{*} p<0.05,{ }^{* *} p<0.005,{ }^{* * *} p<0.0005 . n=5$ per condition. 


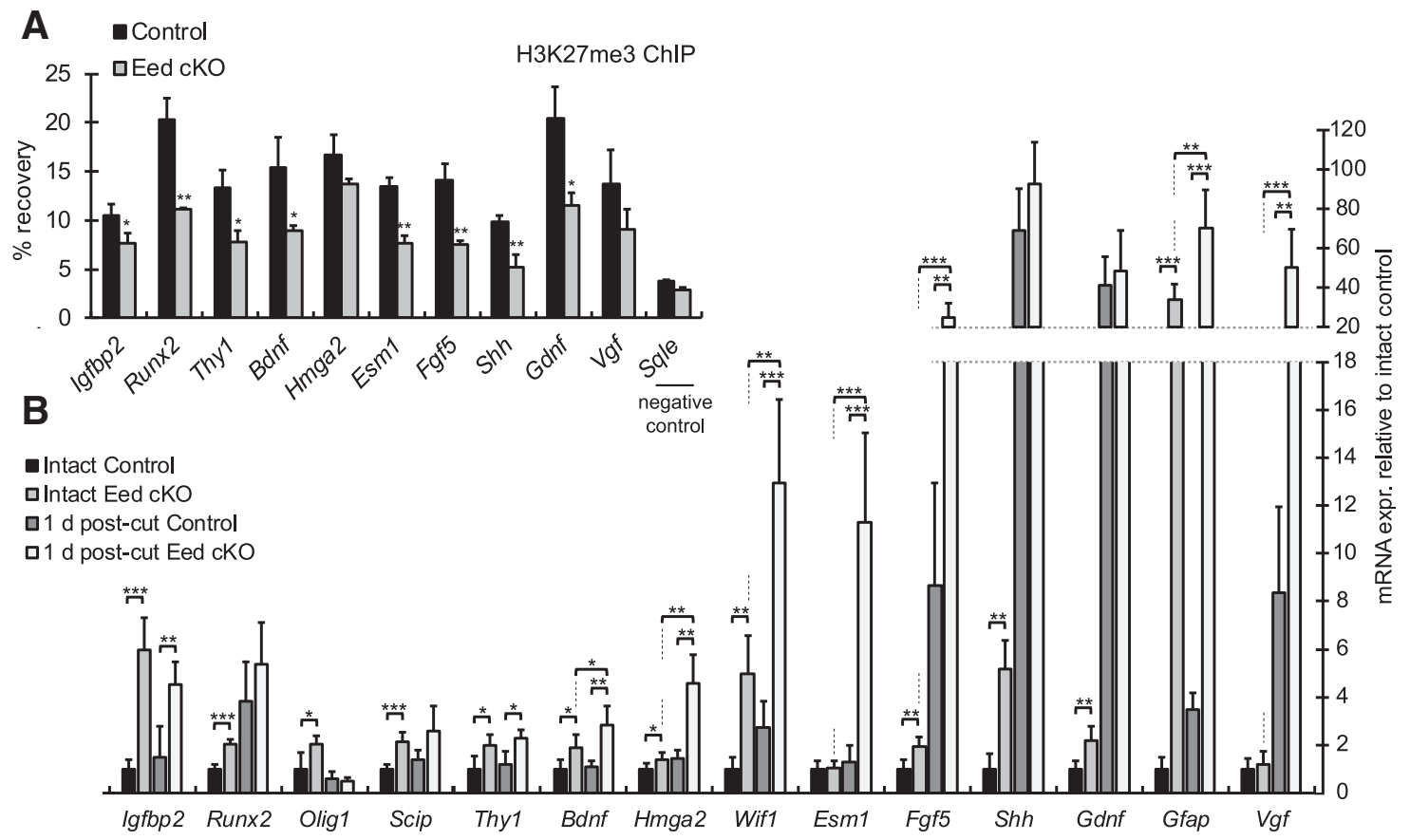

Figure 6. H3K27me3 controls the expression of injury-activated genes of Schwann cells. A, ChIP assays showing changes of H3K27me3 in 1 month Eed cK0 sciatic nerves compared with control. An actively transcribed gene squalene epoxidase (Sqle) in Schwann cells displays low levels of H3K27me3. Data are shown as mean \pm SD. ${ }^{*} p<0.05$, ${ }^{* *} p<0.005 . n=3$ per genotype. B, qRT-PCR analysis was used to identify the expression level of injury-activated genes from 2-month Eed cKO and control sciatic nerves in intact condition or $1 \mathrm{~d}$ after injury. Expression levels were normalized with Gapdh. Data are shown as mean \pm SD. ${ }^{*} p<0.05,{ }^{* *} p<0.005,{ }^{* *} p<0.0005 . n=5$ per genotype and condition.

Eed cKO peripheral nerves (Ma et al., 2015). This suggested that the loss of $\mathrm{H} 3 \mathrm{~K} 27 \mathrm{me} 3$ is sufficient for activation of some genes, but we wished to determine whether H3K27me3 loss may be required for a greater proportion of injury-activated genes. This model would suggest that some injury-activated genes may be expressed prematurely (or more highly) if $\mathrm{H} 3 \mathrm{~K} 27 \mathrm{me} 3$ was depleted. Therefore, we investigated how Eed-deficient nerves primed with the reduced level of H3K27 methylation responded to the injury in gene activation. Although $E s m 1$ and $V g f$ were not derepressed in intact Eed cKO nerves, their levels were dramatically higher in Eed-deficient nerves $1 \mathrm{~d}$ after injury, along with other genes such as Bdnf, Hmga2, Wif1, and Fgf5 (Fig. 6B). Notably, Bdnf and Hmga2 become fully induced at 7 and $3 \mathrm{~d}$ after injury, respectively (Barrette et al., 2010; Arthur-Farraj et al., 2012), but Eed-deficient nerves showed premature induction of these genes at $1 \mathrm{~d}$ after injury. In contrast, Olig 1 was modestly induced in the Eed cKO, but its expression did not increase above baseline after injury in either control or Eed-deficient nerves. Based on previous microarray data (Barrette et al., 2010; ArthurFarraj et al., 2012), the peak time point of Olig1 induction after nerve injury is $7 \mathrm{~d}$ and our own control data indicate only a marginal increase at day 1 . The inability of Eed loss to increase Olig1 expression after injury may reflect the requirement of additional factors in addition to c-Jun that are absent at this early time point. However, the premature/higher induction of several genes in nerves primed with the reduced methylation suggests that demethylation of $\mathrm{H} 3 \mathrm{~K} 27$ is required and is a rate-limiting step in the activation of a larger subset of injury-activated genes beyond those that we have described previously (Ma et al., 2015), in which $\mathrm{H} 3 \mathrm{~K} 27 \mathrm{me} 3$ loss appeared to be necessary and sufficient.

\section{Injury regulation of the $\mathrm{H} 3 \mathrm{~K} 4 \mathrm{me} 3$ promoter mark}

To gain insight into how H3K27 demethylation could activate genes after nerve injury, we also examined the injury-induced changes of $\mathrm{H} 3 \mathrm{~K} 4 \mathrm{me} 3$, which is most often associated with active promoters (Mikkelsen et al., 2007; van Ingen et al., 2008; Lauberth et al., 2013). The trimethylation of H3K4 is often inversely correlated with trimethylation of H3K27 (Agger et al., 2007; Issaeva et al., 2007; Pasini et al., 2008). Surprisingly, the ChIP-seq mapping revealed the presence of $\mathrm{H} 3 \mathrm{~K} 4 \mathrm{me} 3$ at $54 \%$ of injury-activated genes ( $\geq 5$-fold induction after injury) of uninjured nerves (sham condition). The somewhat high percentage of H3K4me3-bound transcription start sites may be due to basal expression levels of some genes before injury, such as $\mathrm{p} 75^{\mathrm{NTR} /}$ Ngfr (Cosgaya et al., 2002). However, it has been shown that $\mathrm{H} 3 \mathrm{~K} 4 \mathrm{me} 3$ is found on poised promoters that are also associated with H3K27me3 (Mikkelsen et al., 2007; Paige et al., 2012).

Consistent with this possibility, the mapping also displayed both H3K27me3 and H3K4me3 at promoters of 7\% of injuryactivated genes that are silenced in NCC and throughout Schwann cell development, including Shh, Fgf5, Gdnf, Olig1, and Wif1 (Fig. 7A). In particular, Shh, Olig1, and Gdnf were reported to be silenced in mature myelinated nerves and immature Schwann cells (Arthur-Farraj et al., 2012; Lin et al., 2015), so the H3K4me3 signal was less likely from any active promoters. In contrast to these, the transcription start sites of silenced genes insensitive to injury, such as Tekt3 and Barhl2, lack H3K4me3. The map from $1 \mathrm{~d}$ after injury showed that the H3K4me3 was increased and/or broadened to a certain degree at some injuryactivated genes such as Shh, Hmga2, Fgf5, and Gdnf. Overall, our data indicate that distal enhancers of injury-induced genes are not poised or "premarked" by characteristics of enhancers nor are they marked with H3K27me3. However, many injuryinduced genes have promoters that appear to be primed with H3K4me3 before injury.

Because H3K27me3 recruits RBP2 demethylase, which removes H3K4me3 (Pasini et al., 2008), we investigated whether demethylation of $\mathrm{H} 3 \mathrm{~K} 27$ is sufficient to induce trimethylation of 
A H3K4me3 ChIP-seq

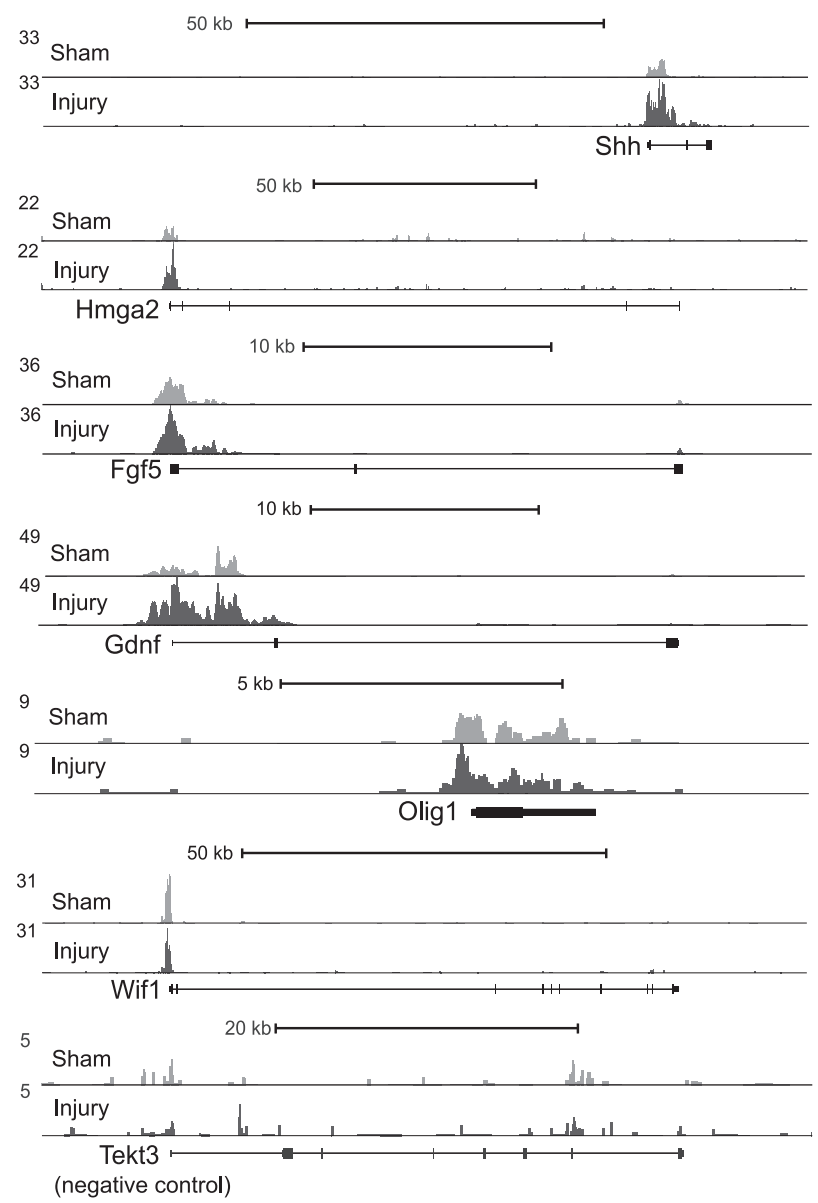

B

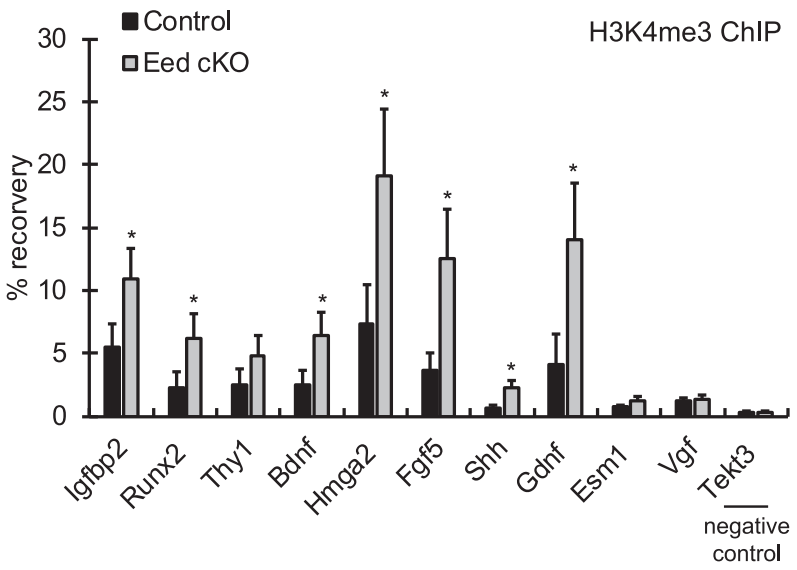

Figure 7. The active histone mark H3K4me3 premarks the transcriptional start sites of injury-activated genes of mature myelinated nerves and increases after injury. $\boldsymbol{A}$, ChIP-seq mapping of H3K4me3 was performed in rat sciatic nerves of sham (light gray) and $1 \mathrm{~d}$ after injury (dark gray). The transcription start site (TSS) is on the left. B, ChIP-qPCR showing changes of $\mathrm{H} 3 \mathrm{~K} 4 \mathrm{me} 3$ in 1-month Eed cKO sciatic nerves compared with control. A silenced gene Tekt3 in Schwann cells displays a lack of H3K4me3.

H3K4 in Schwann cells. ChIP-qPCR analysis identified an increase of $\mathrm{H} 3 \mathrm{~K} 4 \mathrm{me} 3$ at nearby transcriptional start sites of Eeddeficient nerves, in which $\mathrm{H} 3 \mathrm{~K} 27 \mathrm{me} 3$ level is reduced compared with control nerves (Fig. $7 B$ ), and the induction was correlated to derepression of genes (Fig. 6B). Consistent with the above ChIPseq analysis, the analysis showed a significant level of $\mathrm{H} 3 \mathrm{~K} 4 \mathrm{me} 3$ at injury-activated genes compared with a silenced gene, Tekt3, in control nerves. This result would explain our observations that demethylation of $\mathrm{H} 3 \mathrm{~K} 27$ after injury leads to the induction of the $\mathrm{H} 3 \mathrm{~K} 4 \mathrm{me} 3$ active promoter mark at some injury-activated genes.

\section{Discussion}

Studies of Schwann cell responses after nerve injury have demonstrated the extensive reprogramming of the Schwann cell transcriptome (Nagarajan et al., 2002; Bosse et al., 2006; Barrette et al., 2010; Arthur-Farraj et al., 2012). The observed changes include repression of the myelin program, but also activation of several genes that are not normally expressed in Schwann cell development. Studies of the c-Jun transcription factor and the Wlds mutant have shown that the rapid reprogramming is vital to the regenerative response to nerve injury (Arthur-Farraj et al., 2012). Although it was expected that transcriptional reprogramming would also require epigenomic changes, the specific mechanisms have not been characterized. In previous work, an important clue to one of the mechanisms became apparent when we found that depletion of H3K27 methylation by a Schwanncell-specific knock-out of the Eed subunit of the PRC2 complex was sufficient to activate several injury genes (Ma et al., 2015). Profiling of $\mathrm{H} 3 \mathrm{~K} 27 \mathrm{me} 3$ in mature nerve in vivo revealed that $\sim 20 \%$ of injury-activated genes are associated with the repressive H3K27me3 mark and this includes several well known injuryinduced genes that play a role in nerve regeneration, such as $G d n f$, $B d n f$, and Shh (Zhang et al., 2000; Pepinsky et al., 2002; Calcutt et al., 2003; Song et al., 2006; Hashimoto et al., 2008; Fontana et al., 2012; Wilhelm et al., 2012; Martinez et al., 2015). The functions of other genes, such as the Runx transcription factors and Fgf5, have not been characterized, although they are strongly induced after nerve injury (Scarlato et al., 2001; Barrette et al., 2010; Hung et al., 2015).

Although c-Jun is required for full activation of several genes after nerve injury, many of these genes are partially induced by injury even in the absence of c-Jun (Arthur-Farraj et al., 2012). In addition, c-Jun is required for full induction of $\sim 100$ genes after nerve injury, indicating that other mechanisms are involved in the reprogramming of Schwann cells. To understand the mechanism of Schwann cell reprogramming after injury, it is important to identify the mechanisms by which many injury-inducible genes are repressed or silenced before injury. In this effort, we have been aided by our recent identification of injury-inducible enhancers that were identified through analysis of an active enhancer mark, H3K27ac, in injured nerve (Hung et al., 2015). Previous studies had indicated that many enhancers in stem cell development are at least temporarily in a "poised" state in which there is open chromatin and association with an active enhancer mark (H3K4me1), along with repressive H3K27me3 (RadaIglesias et al., 2011; Rada-Iglesias et al., 2012; Calo and Wysocka, 2013). Therefore, we had anticipated that enhancers of injuryinduced genes would follow a similar pattern in which the $\mathrm{H} 3 \mathrm{~K} 27 \mathrm{me} 3$ mark in poised enhancers would be replaced with $\mathrm{H} 3 \mathrm{~K} 27 \mathrm{ac}$ as the enhancers were activated. Contrary to our expectations, the ChIP-seq analysis shows that the previously described injury-induced enhancers are largely not premarked by $\mathrm{H} 3 \mathrm{~K} 27 \mathrm{me} 3$ before injury. Instead, H3K27me3 is generally found in the promoters and around transcription start sites of the gene body. Therefore, the reversal of polycomb repression after nerve injury is not generally associated with the formation or activation of distal enhancers of injury genes, but instead is focused on reversal of $\mathrm{H} 3 \mathrm{~K} 27 \mathrm{me} 3$ at promoters and/or gene bodies of injury genes. 
Therefore, our overall model is that full activation of many injury genes requires reversal of polycomb repression at promoters/gene bodies in concert with binding of injury-induced transcription factors such as c-Jun and Runx2 at distal enhancers. For example, there are some common downstream genes of c-Jun and polycomb pathways, such as Shh, Fgf5, Gdnf, and Runx2. Because injury-induced enhancers are not premarked, this would suggest that some injury-induced transcription factors act as pioneer factors to open up the chromatin structure at enhancers of injury-induced genes. Accordingly, a recent study showed that the AP-1 (Jun/Fos) transcription factor can make chromatin accessible for other transcription factors (Biddie et al., 2011).

H3K27 methylation was thought to be relatively stable and therefore a mechanism of long-term transcriptional memory. However, the identification of the H3K27-specific demethylases JMJD3 and UTX demonstrated that polycomb repression can be reversed (Agger et al., 2007; Lee et al., 2007). Therefore, polycomb repression of many injury genes predicts that demethylation of H3K27 contributes directly to activation of a significant number of injury genes. Peripheral nerve injury induces an increase in the protein level of the Jmjd3/Kdm6b H3K27 demethylase (Gomez-Sanchez et al., 2013). We therefore tested the requirement of H3K27 demethylation using GSK-J4 treated nerve explants. The results showed substantial reduction of injury genes that are normally activated in this model. In addition, we also tested whether $\mathrm{H} 3 \mathrm{~K} 27 \mathrm{me} 3$ depletion resulted in premature and/or augmented induction of nerve injury genes. Although loss of H3K27me3 is sufficient for activation of certain injury genes, our results indicate that it is a rate-limiting step for other genes because activation of other injury genes was premature and/or augmented in the Eed cKO. Several genes listed in our analyses, Igfbp2, Fgf5, Shh, Runx2, and Hmga2, were found to be deregulated in other cell types with altered expression of PRC2 components or Jmjd3 (Boyer et al., 2006; Ezhkova et al., 2011; He et al., 2012; Yang et al., 2013; Perrigue et al., 2015), suggesting that $\mathrm{H} 3 \mathrm{~K} 27 \mathrm{me} 3$ is a commonly used epigenetic block that needs to be removed for their activation.

In this study, we have also shown that the reduction of H3K27me3 leads to the induction of trimethylation of H3K4 at the promoter that promotes the binding of general transcription initiation factor TFIID (van Ingen et al., 2008; Lauberth et al., 2013) in peripheral nerves. This was to some extent anticipated because polycomb repression is associated with the RBP2 demethylase, which demethylates H3K4me3 (Pasini et al., 2008). There have been a number of studies describing the bivalent H3K27me3/H3K4me3 state in stem cell analysis (Mikkelsen et al., 2007; Stock et al., 2007; $\mathrm{Ku}$ et al., 2008). This bivalent chromatin signature was thought to repress promoters while keeping them poised, which then resolves upon ES cell differentiation into a H3K4me3-dominant state through H3K27 demethylation (Bernstein et al., 2006; Mikkelsen et al., 2007; Voigt et al., 2012). We do observe overlap of H3K27me3 and $\mathrm{H} 3 \mathrm{~K} 4 \mathrm{me} 3$ at some genes, including some with the same bivalent mark in neural crest analysis. Although our in vivo analysis does not allow us to conclude that a given promoter is associated with both histone modifications in the same cell, the induction of H3K4me3 and derepression of repair Schwann cell genes such as Shh is caused by the Schwann-cell-specific deletion of Eed. In addition, the presence of the bivalent mark at some silenced genes such as Olig1, Gdnf, and Fgf5 in NCCs is consistent with an early establishment of the mark in Schwann cell development (Rada-Iglesias et al., 2012).

Although we have performed in vivo chromatin analysis to retain the important axonal signals affecting Schwann cell development, a limiting factor of our analysis is that sciatic nerve con- tains some endothelial and fibroblast nuclei, although the majority of sciatic nerve nuclei $(>75 \%)$ are Schwann cells (Salonen et al., 1988; Joseph et al., 2004). In addition, 50-80\% of Schwann cells are myelinating and the rest are nonmyelinating Schwann cells (Zorick et al., 1996; Topilko et al., 1997). For those genes expressed at very low levels in mature nerve, this would suggest, although not prove, that their expression is repressed in both Schwann cell types. Nonetheless, the Schwann-cell-specific deletion of Eed leads us to conclude that removal of polycomb repression leads to changes in Schwann cell gene expression.

Aging slows myelin clearance and the onset of functional recovery after injury (Vaughan, 1992) and such delay appears primarily due to a deteriorating response of transcriptional mechanisms of Schwann cells rather than those of neurons (Ceballos et al., 1999; Verdú et al., 2000; Kang and Lichtman, 2013; Painter et al., 2014). Age-dependent epigenetic change can play a role because it was shown that a decline in the brain remyelination with aging is an outcome of the progressive loss of HDACmediated repression (Shen et al., 2008). Our analyses showed that several of injury-activated genes affected by aging, including Fof5, $B d n f$, Gdnf, and Igfbp2 (Painter et al., 2014), are regulated by H3K27me3, which implies that there may be age-related impairment in the demethylation dynamics. Interestingly, aging also causes derepression of some H3K27me3-regulated genes (Shh, Thy1, Wif1, etc.) in intact nerves and Shh appears to be the second-highest overexpressed genes in old nerves compared with young nerves (Verdier et al., 2012). It is therefore worth investigating the alterations brought by aging in H3K27me3 landscape of uninjured nerves and demethylation after injury.

The dramatic plasticity of Schwann cell lineage can be observed also in the enteric and parasympathetic nervous systems where Schwann cell precursors (SCPs) adopt a neuronal fate and lose the Schwann cell marker SOX10 (Dyachuk et al., 2014; Espinosa-Medina et al., 2014; Uesaka et al., 2015). Enteric SCPs, in particular, contribute to $20 \%$ of myenteric and submucosal neurons in the large intestine such that SCP-derived neurogenesis is required for the postnatal maintenance of the neuron population of the enteric nervous system (ENS; Uesaka et al., 2015). In addition, enteric glia retain neurogenic potential and are able to become enteric neurons in response to ENS injury (Laranjeira et al., 2011). The observation that neuron differentiation genes are highly enriched among silenced genes throughout Schwann cell development, with H3K27me3 found in both NCCs and peripheral nerves or H3K27me3-occupied injury-activated genes, raises an intriguing possibility: that demethylation of $\mathrm{H} 3 \mathrm{~K} 27$ takes a place during the parasympathetic nervous system and ENS neurogenesis derived from SCPs or enteric glia after injury. Importantly, Nkx2-2, Olig1, Olig2, Shh, Isl1, Pax3, and Pax6 are among the critical regulators of neuron differentiation and are silenced by H3K27me3, as we have demonstrated using Eeddeficient peripheral nerves.

Our study illustrates H3K27me3 dynamics and regulation of injury-activated genes. Because patients with peripheral nerve injury often face a long rehabilitation period, the findings are of clinical importance and may lead to the identification of tools for sustainable expression of the repair genes that effectively facilitate the process.

\section{References}

Agger K, Cloos PA, Christensen J, Pasini D, Rose S, Rappsilber J, Issaeva I, Canaani E, Salcini AE, Helin K (2007) UTX and JMJD3 are histone $\mathrm{H} 3 \mathrm{~K} 27$ demethylases involved in HOX gene regulation and development. Nature 449:731-734. CrossRef Medline 
Aldiri I, Vetter ML (2012) PRC2 during vertebrate organogenesis: a complex in transition. Dev Biol 367:91-99. CrossRef Medline

Arthur-Farraj PJ, Latouche M, Wilton DK, Quintes S, Chabrol E, Banerjee A, Woodhoo A, Jenkins B, Rahman M, Turmaine M, Wicher GK, Mitter R, Greensmith L, Behrens A, Raivich G, Mirsky R, Jessen KR (2012) c-Jun reprograms Schwann cells of injured nerves to generate a repair cell essential for regeneration. Neuron 75:633-647. CrossRef Medline

Banner LR, Patterson PH (1994) Major changes in the expression of the mRNAs for cholinergic differentiation factor/leukemia inhibitory factor and its receptor after injury to adult peripheral nerves and ganglia. Proc Natl Acad Sci U S A 91:7109-7113. CrossRef Medline

Barrette B, Calvo E, Vallières N, Lacroix S (2010) Transcriptional profiling of the injured sciatic nerve of mice carrying the Wld(S) mutant gene: identification of genes involved in neuroprotection, neuroinflammation, and nerve regeneration. Brain Behav Immun 24:1254-1267. CrossRef Medline

Bernstein BE, Mikkelsen TS, Xie X, Kamal M, Huebert DJ, Cuff J, Fry B, Meissner A, Wernig M, Plath K, Jaenisch R, Wagschal A, Feil R, Schreiber SL, Lander ES (2006) A bivalent chromatin structure marks key developmental genes in embryonic stem cells. Cell 125:315-326. CrossRef Medline

Biddie SC, John S, Sabo PJ, Thurman RE, Johnson TA, Schiltz RL, Miranda TB, Sung MH, Trump S, Lightman SL, Vinson C, Stamatoyannopoulos JA, Hager GL (2011) Transcription factor AP1 potentiates chromatin accessibility and glucocorticoid receptor binding. Mol Cell 43:145-155. CrossRef Medline

Blackledge NP, Rose NR, Klose RJ (2015) Targeting Polycomb systems to regulate gene expression: modifications to a complex story. Nat Rev Mol Cell Biol 16:643-649. CrossRef Medline

Blom CL, Mårtensson LB, Dahlin LB (2014) Nerve injury-induced c-Jun activation in Schwann cells is JNK independent. Biomed Res Int 2014: 392971. CrossRef Medline

Bosse F, Hasenpusch-Theil K, Küry P, Müller HW (2006) Gene expression profiling reveals that peripheral nerve regeneration is a consequence of both novel injury-dependent and reactivated developmental processes. J Neurochem 96:1441-1457. CrossRef Medline

Boyd JG, Gordon T (2003) Glial cell line-derived neurotrophic factor and brain-derived neurotrophic factor sustain the axonal regeneration of chronically axotomized motoneurons in vivo. Exp Neurol 183:610-619. CrossRef Medline

Boyer LA, Plath K, Zeitlinger J, Brambrink T, Medeiros LA, Lee TI, Levine SS, Wernig M, Tajonar A, Ray MK, Bell GW, Otte AP, Vidal M, Gifford DK, Young RA, Jaenisch R (2006) Polycomb complexes repress developmental regulators in murine embryonic stem cells. Nature 441:349-353. CrossRef Medline

Brosius Lutz A, Barres BA (2014) Contrasting the glial response to axon injury in the central and peripheral nervous systems. Dev Cell 28:7-17. CrossRef Medline

Buchstaller J, Sommer L, Bodmer M, Hoffmann R, Suter U, Mantei N (2004) Efficient isolation and gene expression profiling of small numbers of neural crest stem cells and developing Schwann cells. J Neurosci 24:23572365. CrossRef Medline

Calcutt NA, Allendoerfer KL, Mizisin AP, Middlemas A, Freshwater JD, Burgers M, Ranciato R, Delcroix JD, Taylor FR, Shapiro R, Strauch K, Dudek H, Engber TM, Galdes A, Rubin LL, Tomlinson DR (2003) Therapeutic efficacy of sonic hedgehog protein in experimental diabetic neuropathy. J Clin Invest 111:507-514. CrossRef Medline

Calo E, Wysocka J (2013) Modification of enhancer chromatin: what, how, and why? Mol Cell 49:825-837. CrossRef Medline

Ceballos D, Cuadras J, Verdú E, Navarro X (1999) Morphometric and ultrastructural changes with ageing in mouse peripheral nerve. J Anat 195: 563-576. CrossRef Medline

Chen Y, Wang H, Yoon SO, Xu X, Hottiger MO, Svaren J, Nave KA, Kim HA, Olson EN, Lu QR (2011) HDAC-mediated deacetylation of NF- $\kappa \mathrm{B}$ is critical for Schwann cell myelination. Nat Neurosci 14:437-441. CrossRef Medline

Cosgaya JM, Chan JR, Shooter EM (2002) The neurotrophin receptor p75NTR as a positive modulator of myelination. Science 298:1245-1248. CrossRef Medline

Dyachuk V, Furlan A, Shahidi MK, Giovenco M, Kaukua N, Konstantinidou C, Pachnis V, Memic F, Marklund U, Müller T, Birchmeier C, Fried K, Ernfors P, Adameyko I (2014) Neurodevelopment. Parasympathetic neurons originate from nerve-associated peripheral glial progenitors. Science 345:82-87. CrossRef Medline

Espinosa-Medina I, Outin E, Picard CA, Chettouh Z, Dymecki S, Consalez GG, Coppola E, Brunet JF (2014) Neurodevelopment: parasympathetic ganglia derive from Schwann cell precursors. Science 345:87-90. CrossRef Medline

Ezhkova E, Pasolli HA, Parker JS, Stokes N, Su IH, Hannon G, Tarakhovsky A, Fuchs E (2009) Ezh2 orchestrates gene expression for the stepwise differentiation of tissue-specific stem cells. Cell 136:1122-1135. CrossRef Medline

Ezhkova E, Lien WH, Stokes N, Pasolli HA, Silva JM, Fuchs E (2011) EZH1 and EZH2 cogovern histone H3K27 trimethylation and are essential for hair follicle homeostasis and wound repair. Genes Dev 25:485-498. CrossRef Medline

Feltri ML, D’Antonio M, Previtali S, Fasolini M, Messing A, Wrabetz L (1999) P0-Cre transgenic mice for inactivation of adhesion molecules in Schwann cells. Ann N Y Acad Sci 883:116-123. CrossRef Medline

Fogarty M, Richardson WD, Kessaris N (2005) A subset of oligodendrocytes generated from radial glia in the dorsal spinal cord. Development 132: 1951-1959. CrossRef Medline

Fontana X, Hristova M, Da Costa C, Patodia S, Thei L, Makwana M, Spencer-Dene B, Latouche M, Mirsky R, Jessen KR, Klein R, Raivich G, Behrens A (2012) c-Jun in Schwann cells promotes axonal regeneration and motoneuron survival via paracrine signaling. J Cell Biol 198: 127-141. CrossRef Medline

Gomez-Sanchez JA, Gomis-Coloma C, Morenilla-Palao C, Peiro G, Serra E, Serrano M, Cabedo H (2013) Epigenetic induction of the Ink4a/Arf locus prevents Schwann cell overproliferation during nerve regeneration and after tumorigenic challenge. Brain 136:2262-2278. CrossRef Medline

Hashimoto M, Ishii K, Nakamura Y, Watabe K, Kohsaka S, Akazawa C (2008) Neuroprotective effect of sonic hedgehog up-regulated in Schwann cells following sciatic nerve injury. J Neurochem 107:918-927. CrossRef Medline

He A, Ma Q, Cao J, von Gise A, Zhou P, Xie H, Zhang B, Hsing M, Christodoulou DC, Cahan P, Daley GQ, Kong SW, Orkin SH, Seidman CE, Seidman JG, Pu WT (2012) Polycomb repressive complex 2 regulates normal development of the mouse heart. Circ Res 110:406-415. CrossRef Medline

Heinz S, Benner C, Spann N, Bertolino E, Lin YC, Laslo P, Cheng JX, Murre C, Singh H, Glass CK (2010) Simple combinations of lineage-determining transcription factors prime cis-regulatory elements required for macrophage and B cell identities. Mol Cell 38:576-589. CrossRef Medline

Huang da W, Sherman BT, Lempicki RA (2009a) Systematic and integrative analysis of large gene lists using DAVID bioinformatics resources. Nat Protoc 4:44-57. CrossRef Medline

Huang da W, Sherman BT, Lempicki RA (2009b) Bioinformatics enrichment tools: paths toward the comprehensive functional analysis of large gene lists. Nucleic Acids Res 37:1-13. CrossRef Medline

Hung HA, Sun G, Keles S, Svaren J (2015) Dynamic regulation of Schwann cell enhancers after peripheral nerve injury. J Biol Chem 290:6937-6950. CrossRef Medline

Hung H, Kohnken R, Svaren J (2012) The nucleosome remodeling and deacetylase chromatin remodeling $(\mathrm{NuRD})$ complex is required for peripheral nerve myelination. J Neurosci 32:1517-1527. CrossRef Medline

Issaeva I, Zonis Y, Rozovskaia T, Orlovsky K, Croce CM, Nakamura T, Mazo A, Eisenbach L, Canaani E (2007) Knockdown of ALR (MLL2) reveals ALR target genes and leads to alterations in cell adhesion and growth. Mol Cell Biol 27:1889-1903. CrossRef Medline

Jacob C, Christen CN, Pereira JA, Somandin C, Baggiolini A, Lötscher P, Ozçelik M, Tricaud N, Meijer D, Yamaguchi T, Matthias P, Suter U (2011) HDAC1 and HDAC2 control the transcriptional program of myelination and the survival of Schwann cells. Nat Neurosci 14:429-436. CrossRef Medline

Jessen KR, Mirsky R (2016) The repair Schwann cell and its function in regenerating nerves. J Physiol 594:3521-3531. CrossRef Medline

Joseph NM, Mukouyama YS, Mosher JT, Jaegle M, Crone SA, Dormand EL, Lee KF, Meijer D, Anderson DJ, Morrison SJ (2004) Neural crest stem cells undergo multilineage differentiation in developing peripheral nerves to generate endoneurial fibroblasts in addition to Schwann cells. Development 131:5599-5612. CrossRef Medline

Kang H, Lichtman JW (2013) Motor axon regeneration and muscle reinner- 
vation in young adult and aged animals. J Neurosci 33:19480-19491. CrossRef Medline

Kim HA, Mindos T, Parkinson DB (2013) Plastic fantastic: Schwann cells and repair of the peripheral nervous system. Stem Cells Transl Med 2:553-557. CrossRef Medline

Kim Y, Remacle AG, Chernov AV, Liu H, Shubayev I, Lai C, Dolkas J, Shiryaev SA, Golubkov VS, Mizisin AP, Strongin AY, Shubayev VI (2012) The MMP-9/TIMP-1 axis controls the status of differentiation and function of myelin-forming Schwann cells in nerve regeneration. PLoS One 7:e33664. CrossRef Medline

Kruidenier L et al. (2012) A selective jumonji H3K27 demethylase inhibitor modulates the proinflammatory macrophage response. Nature 488: 404-408. CrossRef Medline

Ku M, Koche RP, Rheinbay E, Mendenhall EM, Endoh M, Mikkelsen TS, Presser A, Nusbaum C, Xie X, Chi AS, Adli M, Kasif S, Ptaszek LM, Cowan CA, Lander ES, Koseki H, Bernstein BE (2008) Genomewide analysis of PRC1 and PRC2 occupancy identifies two classes of bivalent domains. PLoS Genet 4:e1000242. CrossRef Medline

Laranjeira C, Sandgren K, Kessaris N, Richardson W, Potocnik A, Vanden Berghe P, Pachnis V (2011) Glial cells in the mouse enteric nervous system can undergo neurogenesis in response to injury. J Clin Invest 121:3412-3424. CrossRef Medline

Lauberth SM, Nakayama T, Wu X, Ferris AL, Tang Z, Hughes SH, Roeder RG (2013) H3K4me3 interactions with TAF3 regulate preinitiation complex assembly and selective gene activation. Cell 152:1021-1036. CrossRef Medline

Lee MG, Villa R, Trojer P, Norman J, Yan KP, Reinberg D, Di Croce L, Shiekhattar R (2007) Demethylation of H3K27 regulates polycomb recruitment and H2A ubiquitination. Science 318:447-450. CrossRef Medline

Lin HP, Oksuz I, Hurley E, Wrabetz L, Awatramani R (2015) Microprocessor complex subunit DiGeorge syndrome critical region gene 8 (Dgcr8) is required for schwann cell myelination and myelin maintenance. J Biol Chem 290:24294-24307. CrossRef Medline

Ma KH, Hung HA, Srinivasan R, Xie H, Orkin SH, Svaren J (2015) Regulation of peripheral nerve myelin maintenance by gene repression through polycomb repressive complex 2. J Neurosci 35:8640-8652. CrossRef Medline

Mårtensson L, Gustavsson P, Dahlin LB, Kanje M (2007) Activation of extracellular-signal-regulated kinase-1/2 precedes and is required for injury-induced Schwann cell proliferation. Neuroreport 18:957-961. CrossRef Medline

Martinez JA, Kobayashi M, Krishnan A, Webber C, Christie K, Guo G, Singh V, Zochodne DW (2015) Intrinsic facilitation of adult peripheral nerve regeneration by the Sonic hedgehog morphogen. Exp Neurol 271: 493-505. CrossRef Medline

Mikkelsen TS et al. (2007) Genome-wide maps of chromatin state in pluripotent and lineage-committed cells. Nature 448:553-560. CrossRef Medline

Montgomery ND, Yee D, Chen A, Kalantry S, Chamberlain SJ, Otte AP, Magnuson T (2005) The murine polycomb group protein Eed is required for global histone H3 lysine-27 methylation. Curr Biol 15:942-947. CrossRef Medline

Mueller M, Leonhard C, Wacker K, Ringelstein EB, Okabe M, Hickey WF, Kiefer R (2003) Macrophage response to peripheral nerve injury: the quantitative contribution of resident and hematogenous macrophages. Lab Invest 83:175-185. CrossRef Medline

Nagarajan R, Le N, Mahoney H, Araki T, Milbrandt J (2002) Deciphering peripheral nerve myelination by using Schwann cell expression profiling. Proc Natl Acad Sci U S A 99:8998-9003. CrossRef Medline

Oppenheim RW, Houenou LJ, Johnson JE, Lin LF, Li L, Lo AC, Newsome AL, Prevette DM, Wang S (1995) Developing motor neurons rescued from programmed and axotomy-induced cell death by GDNF. Nature 373: 344-346. CrossRef Medline

Orentas DM, Hayes JE, Dyer KL, Miller RH (1999) Sonic hedgehog signaling is required during the appearance of spinal cord oligodendrocyte precursors. Development 126:2419-2429. Medline

Paige SL, Thomas S, Stoick-Cooper CL, Wang H, Maves L, Sandstrom R, Pabon L, Reinecke H, Pratt G, Keller G, Moon RT, Stamatoyannopoulos J, Murry CE (2012) A temporal chromatin signature in human embryonic stem cells identifies regulators of cardiac development. Cell 151: 221-232. CrossRef Medline

Painter MW, Brosius Lutz A, Cheng YC, Latremoliere A, Duong K, Miller CM, Posada S, Cobos EJ, Zhang AX, Wagers AJ, Havton LA, Barres B,
Omura T, Woolf CJ (2014) Diminished Schwann cell repair responses underlie age-associated impaired axonal regeneration. Neuron 83: 331-343. CrossRef Medline

Palomer E, Carretero J, Benvegnù S, Dotti CG, Martin MG (2016) Neuronal activity controls Bdnf expression via Polycomb de-repression and CREB/ CBP/JMJD3 activation in mature neurons. Nat Commun 7:11081. CrossRef Medline

Pasini D, Bracken AP, Jensen MR, Lazzerini Denchi E, Helin K (2004) Suz12 is essential for mouse development and for EZH2 histone methyltransferase activity. EMBO J 23:4061-4071. CrossRef Medline

Pasini D, Hansen KH, Christensen J, Agger K, Cloos PA, Helin K (2008) Coordinated regulation of transcriptional repression by the RBP2 H3K4 demethylase and Polycomb-Repressive Complex 2. Genes Dev 22: 1345-1355. CrossRef Medline

Patodia S, Raivich G (2012a) Downstream effector molecules in successful peripheral nerve regeneration. Cell Tissue Res 349:15-26. CrossRef Medline

Patodia S, Raivich G (2012b) Role of transcription factors in peripheral nerve regeneration. Front Mol Neurosci 5:8. CrossRef Medline

Pepinsky RB, Shapiro RI, Wang S, Chakraborty A, Gill A, Lepage DJ, Wen D, Rayhorn P, Horan GS, Taylor FR, Garber EA, Galdes A, Engber TM (2002) Long-acting forms of Sonic hedgehog with improved pharmacokinetic and pharmacodynamic properties are efficacious in a nerve injury model. J Pharm Sci 91:371-387. CrossRef Medline

Perkins NM, Tracey DJ (2000) Hyperalgesia due to nerve injury: role of neutrophils. Neuroscience 101:745-757. CrossRef Medline

Perrigue PM, Silva ME, Warden CD, Feng NL, Reid MA, Mota DJ, Joseph LP, Tian YI, Glackin CA, Gutova M, Najbauer J, Aboody KS, Barish ME (2015) The histone demethylase jumonji coordinates cellular senescence including secretion of neural stem cell-attracting cytokines. Mol Cancer Res 13:636-650. CrossRef Medline

Piirsoo M, Kaljas A, Tamm K, Timmusk T (2010) Expression of NGF and GDNF family members and their receptors during peripheral nerve development and differentiation of Schwann cells in vitro. Neurosci Lett 469:135-140. CrossRef Medline

Rada-Iglesias A, Bajpai R, Swigut T, Brugmann SA, Flynn RA, Wysocka J (2011) A unique chromatin signature uncovers early developmental enhancers in humans. Nature 470:279-283. CrossRef Medline

Rada-Iglesias A, Bajpai R, Prescott S, Brugmann SA, Swigut T, Wysocka J (2012) Epigenomic annotation of enhancers predicts transcriptional regulators of human neural crest. Cell Stem Cell 11:633-648. CrossRef Medline

Salonen V, Aho H, Röyttä M, Peltonen J (1988) Quantitation of Schwann cells and endoneurial fibroblast-like cells after experimental nerve trauma. Acta Neuropathol 75:331-336. CrossRef Medline

Scarlato M, Xu T, Bannerman P, Beesley J, Reddy UR, Rostami A, Scherer SS, Pleasure D (2001) Axon-Schwann cell interactions regulate the expression of fibroblast growth factor-5 (FGF-5). J Neurosci Res 66:16-22. CrossRef Medline

Schuster K, Dambly-Chaudière C, Ghysen A (2010) Glial cell line-derived neurotrophic factor defines the path of developing and regenerating axons in the lateral line system of zebrafish. Proc Natl Acad Sci U S A 107: 19531-19536. CrossRef Medline

Schwarz D, Varum S, Zemke M, Schöler A, Baggiolini A, Draganova K, Koseki H, Schübeler D, Sommer L (2014) Ezh2 is required for neural crestderived cartilage and bone formation. Development 141:867-877. CrossRef Medline

Shen S, Sandoval J, Swiss VA, Li J, Dupree J, Franklin RJ, Casaccia-Bonnefil P (2008) Age-dependent epigenetic control of differentiation inhibitors is critical for remyelination efficiency. Nat Neurosci 11:1024-1034. CrossRef Medline

Shin YK, Jang SY, Park JY, Park SY, Lee HJ, Suh DJ, Park HT (2013) The Neuregulin-Rac-MKK7 pathway regulates antagonistic c-jun/Krox20 expression in Schwann cell dedifferentiation. Glia 61:892-904. CrossRef Medline

Song XY, Zhou FH, Zhong JH, Wu LL, Zhou XF (2006) Knockout of p75(NTR) impairs re-myelination of injured sciatic nerve in mice. J Neurochem 96:833-842. CrossRef Medline

Stock JK, Giadrossi S, Casanova M, Brookes E, Vidal M, Koseki H, Brockdorff N, Fisher AG, Pombo A (2007) Ring1-mediated ubiquitination of H2A restrains poised RNA polymerase II at bivalent genes in mouse ES cells. Nat Cell Biol 9:1428-1435. CrossRef Medline

Topilko P, Levi G, Merlo G, Mantero S, Desmarquet C, Mancardi G, Charnay P (1997) Differential regulation of the zinc finger genes Krox-20 and 
Krox-24 (Egr-1) suggests antagonistic roles in Schwann cells. J Neurosci Res 50:702-712. Medline

Uesaka T, Nagashimada M, Enomoto H (2015) Neuronal differentiation in Schwann cell lineage underlies postnatal neurogenesis in the enteric nervous system. J Neurosci 35:9879-9888. CrossRef Medline

Vallstedt A, Klos JM, Ericson J (2005) Multiple dorsoventral origins of oligodendrocyte generation in the spinal cord and hindbrain. Neuron 45: 55-67. CrossRef Medline

van Ingen $\mathrm{H}$, van Schaik FM, Wienk H, Ballering J, Rehmann H, Dechesne AC, Kruijzer JA, Liskamp RM, Timmers HT, Boelens R (2008) Structural insight into the recognition of the H3K4me3 mark by the TFIID subunit TAF3. Structure 16:1245-1256. CrossRef Medline

Vaughan DW (1992) Effects of advancing age on peripheral nerve regeneration. J Comp Neurol 323:219-237. CrossRef Medline

Verdier V, Csárdi G, de Preux-Charles AS, Médard JJ, Smit AB, Verheijen MH, Bergmann S, Chrast R (2012) Aging of myelinating glial cells predominantly affects lipid metabolism and immune response pathways. Glia 60:751-760. CrossRef Medline

Verdú E, Ceballos D, Vilches JJ, Navarro X (2000) Influence of aging on peripheral nerve function and regeneration. J Peripher Nerv Syst 5: 191-208. CrossRef Medline

Viré E, Brenner C, Deplus R, Blanchon L, Fraga M, Didelot C, Morey L, Van Eynde A, Bernard D, Vanderwinden JM, Bollen M, Esteller M, Di Croce L, de Launoit Y, Fuks F (2006) The Polycomb group protein EZH2 directly controls DNA methylation. Nature 439:871-874. Medline

Voigt P, LeRoy G, Drury WJ 3rd, Zee BM, Son J, Beck DB, Young NL, Garcia
BA, Reinberg D (2012) Asymmetrically modified nucleosomes. Cell 151:181-193. CrossRef Medline

Weider M, Küspert M, Bischof M, Vogl MR, Hornig J, Loy K, Kosian T, Müller J, Hillgärtner S, Tamm ER, Metzger D, Wegner M (2012) Chromatin-remodeling factor Brg1 is required for Schwann cell differentiation and myelination. Dev Cell 23:193-201. CrossRef Medline

Wilhelm JC, Xu M, Cucoranu D, Chmielewski S, Holmes T, Lau KS, Bassell GJ, English AW (2012) Cooperative roles of BDNF expression in neurons and Schwann cells are modulated by exercise to facilitate nerve regeneration. J Neurosci 32:5002-5009. CrossRef Medline

Xie H, Xu J, Hsu JH, Nguyen M, Fujiwara Y, Peng C, Orkin SH (2014) Polycomb repressive complex 2 regulates normal hematopoietic stem cell function in a developmental-stage-specific manner. Cell Stem Cell 14: 68-80. CrossRef Medline

Yan Q, Matheson C, Lopez OT (1995) In vivo neurotrophic effects of GDNF on neonatal and adult facial motor neurons. Nature 373:341-344. CrossRef Medline

Yang D, Okamura H, Nakashima Y, Haneji T (2013) Histone demethylase Jmjd3 regulates osteoblast differentiation via transcription factors Runx2 and osterix. J Biol Chem 288:33530-33541. CrossRef Medline

Zhang JY, Luo XG, Xian CJ, Liu ZH, Zhou XF (2000) Endogenous BDNF is required for myelination and regeneration of injured sciatic nerve in rodents. Eur J Neurosci 12:4171-4180. Medline

Zorick TS, Syroid DE, Arroyo E, Scherer SS, Lemke G (1996) The transcription factors SCIP and Krox-20 mark distinct stages and cell fates in Schwann cell differentiation. Mol Cell Neurosci 8:129-145. CrossRef Medline 